
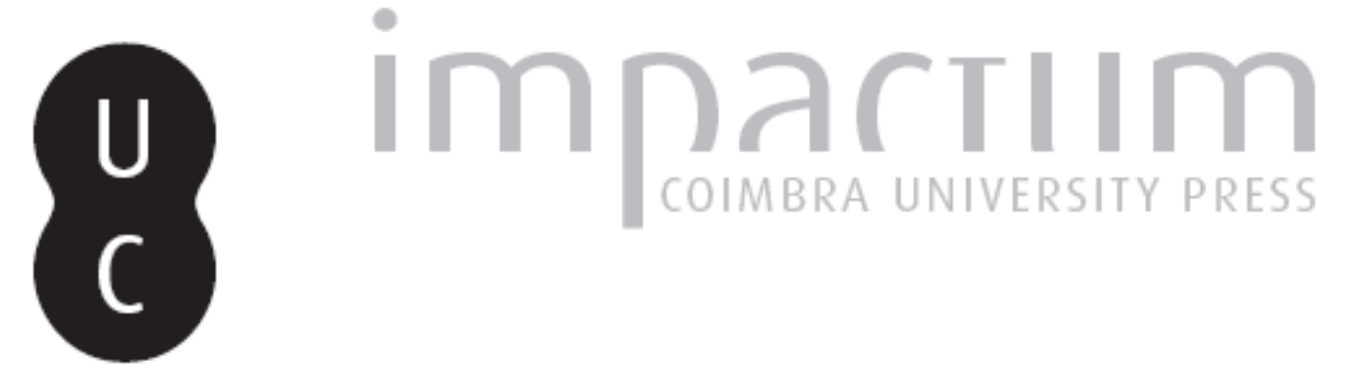

\title{
Paisagem e monumentos de Portugal: Images do ressurgimento nacional
}

Autor(es): Correia, Luís Miguel

Publicado por: Imprensa da Universidade de Coimbra

URL persistente:

URI:http://hdl.handle.net/10316.2/44861

DOI:

DOI:https://doi.org/10.14195/1647-8622_18_10

Accessed : $\quad$ 26-Apr-2023 09:57:29

A navegação consulta e descarregamento dos títulos inseridos nas Bibliotecas Digitais UC Digitalis, UC Pombalina e UC Impactum, pressupõem a aceitação plena e sem reservas dos Termos e Condições de Uso destas Bibliotecas Digitais, disponíveis em https://digitalis.uc.pt/pt-pt/termos.

Conforme exposto nos referidos Termos e Condições de Uso, o descarregamento de títulos de acesso restrito requer uma licença válida de autorização devendo o utilizador aceder ao(s) documento(s) a partir de um endereço de IP da instituição detentora da supramencionada licença.

Ao utilizador é apenas permitido o descarregamento para uso pessoal, pelo que o emprego do(s) título(s) descarregado(s) para outro fim, designadamente comercial, carece de autorização do respetivo autor ou editor da obra.

Na medida em que todas as obras da UC Digitalis se encontram protegidas pelo Código do Direito de Autor e Direitos Conexos e demais legislação aplicável, toda a cópia, parcial ou total, deste documento, nos casos em que é legalmente admitida, deverá conter ou fazer-se acompanhar por este aviso.

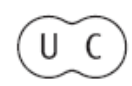




\section{ESTUDOSDOSÉCULO}

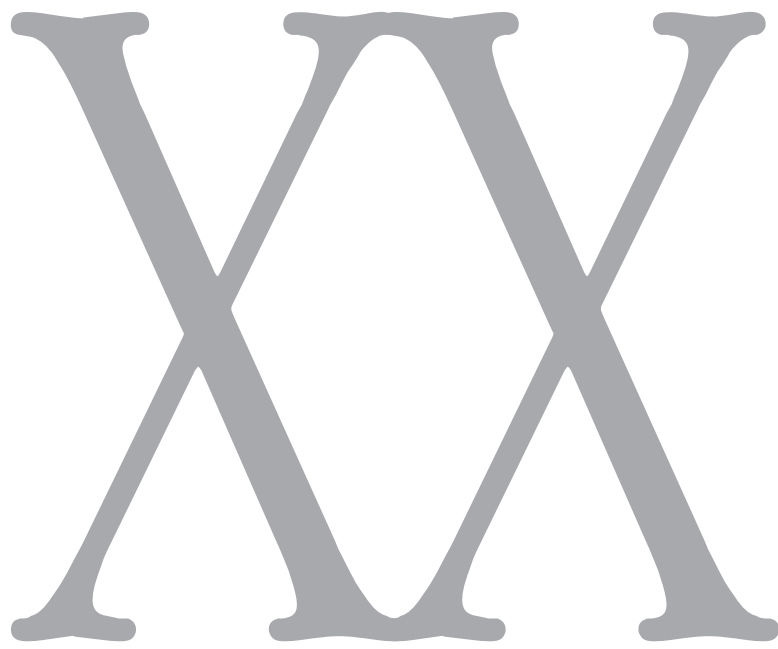

número $18 \bullet 2018$

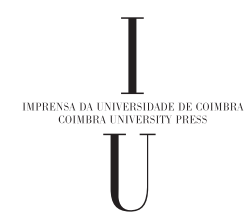




\section{Paisagem e Monumentos de Portugal Images do Ressurgimento Nacional}

\section{Landscape and Cultural Heritage from Portugal Images of National Resurgence}

\section{Luís Miguel Correia}

Luís Miguel Correia, Investigador Integrado do Centro de Estudos Interdisciplinares do Século XX - CEIS20. Professor Auxiliar do Departamento de Arquitetura da Faculdade de Ciências e Tecnologia da Universidade de Coimbra. Email: lcorreia@darq.uc.pt. 
PAISAGEM E MONUMENTOS DE PORTUGAL. IMAGES DO RESSURGIMENTO NACIONAL

Será o Portugal contemporâneo corolário das conquistas da Revolução dos Cravos? Restringindo-nos ao caso da arquitectura, podemos indagar se esta readquiriu a sua autonomia disciplinar, lavrando na terra a desejada democratizaçáo do espaço e, ainda, averiguar se foi responsável pela memorização de muitos dos projectos elaborados no pós-25 de Abril. Conquanto julguemos pertinente a indagação, não nos propomos proceder a uma análise exaustiva da conjuntura actual, embora admitamos que esta evidencia a influência de mais de quarenta anos de salazarismo. Entre o fim da década de trinta e o início da de quarenta assistiu-se a um período de afirmação e consolidação das ideias desenhadas por Oliveira Salazar para o Império Português, durante o qual a imagem, tangível ou intangível, do território desempenhou um papel preponderante na pressagiada restauração material, moral e nacional. Com base sobretudo em publicaçóes editadas pela propaganda nacional, como Images Portugaises [1939], Paisagem e Monumentos de Portugal (1940), Obras Públicas: Caderno do Ressurgimento Nacional [1943] e noutras com elas correlacionadas, comprovaremos como pouco antes do advento da $2 .^{a}$ Guerra Mundial já se desvendava na paisagem portuguesa um vasto conjunto de traços distintivos do projecto salazarista, cuja memória ainda hoje remanesce em diferentes lugares.

Palavras-chave: Salazarismo, Paisagem, Monumentos Nacionais, Propaganda, Obras Públicas.
LANDSCAPE AND CULTURAL HERITAGE FROM

PORTUGAL. IMAGES OF NATIONAL RESURGENCE

Shall we consider the contemporary Portugal as a result of the conquests from the so called Carnation Revolution (Revolução dos Cravos)? If we only contemplate the case of architecture, we may question if this discipline has regained its disciplinary autonomy, building the wanted democratization of space and also determine if it has been responsible for the memorization of many of the projects conducted in the post 25th April times. Although we consider this inquiry as adequate, it is not our purpose to pursue an exhaustive analysis of the current situation, although we can accept that it denotes the influence of more than forty years of Salazarism. Between the end of the thirties and beginning of the forties, we face a period of reinforcement and consolidation of the ideas outlined by Oliveira Salazar for the Portuguese Empire. During that period the tangible or intangible image of the territory has played a major role in the announced material, moral and national restoration. Based mainly on publications edited by national propaganda, namely Images Portugaises [1939], Paisagem e Monumentos de Portugal (1940), Obras Públicas: Caderno do Ressurgimento Nacional [1943], as well as with other correlated works, we will demonstrate how, short before the advent of World War II, it was already possible to discover in the Portuguese landscape a significant array of distinctive features of the Salazarist project, whose memory still remains today in different places.

Keywords: Salazarism, Landscape, Cultural Heritage, Propaganda, Public Works.
PAYSAGE ET MONUMENTS DU PORTUGAL. IMAGES DE LA RÉSURGENCE NATIONALE

Le Portugal contemporain est-il un corollaire des réalisations de la Révolution des Eillets? En nous limitant au cas de l'architecture, nous pouvons nous demander si celle-ci a retrouvé son autonomie disciplinaire, la démocratisation souhaitée de l'espace labourant la terre, mais également établir si elle a été responsable de la mémorisation d'un grand nombre des projets développés après le 25 avril. Bien que nous jugions pertinente l'enquête, nous ne proposons pas de procéder à une analyse exhaustive de la conjoncture actuelle, bien que nous admettions qu'elle témoigne de l'influence de plus de quarante ans de salazarisme. Entre la fin des années trente et le début des années quarante, nous avons assisté à une période d'affirmation et de consolidation des idées conçues par Oliveira Salazar pour l'Empire portugais, au cours de laquelle l'image, tangible ou intangible, du territoire a joué un rôle de premier plan dans la restauration matérielle, morale et nationale présagée. À partir essentiellement des publications éditées par la propagande nationale, comme Images Portugaises [1939], Paisagem e Monumentos de Portugal (1940), Obras Públicas: Caderno do Ressurgimento Nacional [1943] et d'autres liées à celle-ci, nous prouverons comment juste avant la Deuxième Première Guerre mondiale, un vaste ensemble de caractéristiques distinctives du projet salazariste, qui existent encore aujourd'hui à différents endroits, ont été révélées dans le paysage portugais.

Mots clés: Salazarisme, Paysage, Monuments nationaux, Propagande, Travaux publics. 


\section{Breve enquadramento}

É sabido que a historiografia europeia (e mundial) tem amplamente analisado casos em que a história, a paisagem e a arquitectura têm sido usadas e instrumentalizadas com fins ideológicos e políticos, em especial quando sob o domínio de regimes autoritários e totalitários. Tendo em conta exclusivamente o tema e os objectivos do presente artigo, que à partida o título deixa subentender, por certo melhor se compreenderá o quadro experimentado em Portugal à época do regime superintendido por António de Oliveira Salazar à luz das circunstâncias vividas na Alemanha, na Itália e em Espanha durante o comando de Adolf Hitler, Benito Mussolini e Francisco Franco, respectivamente. Um panorama nacional que nos anos de instituição e consolidação da Ditadura Nacional se reviu sobretudo na congénere italiana. Segundo recordámos num texto ${ }^{1}$ publicado na revista de Estudos Italianos em Portugal, no caso subordinada a Arquitectos Italianos em Portugal, Benito Mussolini não era arquitecto de formação e, ao que se conhece, nunca pisou solo português. Todavia, é consabido que a doutrina política e também a figura dominadora do ditador italiano foram paradigma para Oliveira Salazar na criaçáo do Estado Novo. Daqui se possa depreender que, "postado sobre a secretária de Oliveira Salazar [alusáo directa a uma fotografia publicada na revista Life em 1940, da autoria de Bernard Hoffman], Il Duce tenha [simbolicamente] ministrado, em parte, uma lição sobre o lugar da história no Nuovo Stato"2. Desde logo, acautelando a devida distância entre as duas ditaduras e seus líderes, importou reconhecer como de forma semelhante ao desígnio perfilhado pelo aliado italiano, Oliveira Salazar, a partir de 5 de Julho de 1932, se comprometeu pessoalmente com o restauro de certos monumentos nacionais que, ao serviço de pretensa política de verdade, legitimassem e pudessem enaltecer a grandiosidade dos seus princípios e realizaçôes. Com base numa visão consagrada a $o$ antes e a $o$ depois, presenciámos destarte como Il Duce, através do uso dos vestígios da Roma Antiga, e Oliveira Salazar, com recurso, por exemplo, aos envelhecidos castelos portugueses ${ }^{3}$, sempre procuraram, apud La politique du patrimoine de Marc Guillaume, "recolocar o presente conturbado no imaginário de uma continuidade com um passado tranquilizador, e sobretudo esquecer o passado recente" ${ }^{4}$.

Ainda que não seja nosso intento cotejar o modo como o fascismo italiano e o regime salazarista, entre demais estados ditatoriais, utilizaram determinadas estruturas passadas e uma nova arquitectura em favor de uma atmosfera sonhada, é manifesto que houve uma relação directa entre obra construída e obra política. Assim o constata, a título de exemplo, igualmente Elisa Pegorin num artigo dado à estampa na referida revista de Estudos Italianos em Portugal: Architettura e regime tra Italia e Portogallo. Relazione

\footnotetext{
${ }^{1}$ CORREIA, Luís Miguel - "Il Duce à secretária de Salazar. Lição sobre o lugar da história no Nuovo Stato”. Estudos Italianos em Portugal. Lisboa: Instituto de Estudos Italianos. ISSN 0870-8584. Nova Série, N.o 12 (2017) p. 69-82.

2 Ibidem. p. 81.

${ }^{3}$ CORREIA, Luís Miguel - Castelos em Portugal: Retrato do seu perfil arquitectónico [1509-1949]. 2. ${ }^{\mathrm{ed}}$. Coimbra: Imprensa da Universidade de Coimbra, 2011. 475 p. ISBN 9789892600604.

${ }^{4}$ GUILlaUmE, Marc - A politica do património. Trad. Joana Caspurro. Porto: Campo das Letras, 2003. ISBN 972-610-704-0. p. 142 e 143.
} 


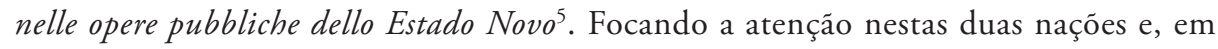
específico, na forma como as diversas obras públicas italianas inspiraram a arquitectura portuguesa, Elisa Pegorin reconhece, com base nos testemunhos de alguns autores que têm dedicado a sua investigação a este tema ${ }^{6}$, que "[l]' architettura totalitaria risultava dalla volontà di controllo da parte dello stato sulla collettività" ${ }^{2}$. Por isso, representava um "strumento privilegiato per la facilità della sua manipolazione nel disegno e per la sua dimensione, durabilità e utilizzo obbligatorio di opera-edificio, spazio, città, e in questi termini un veicolo di propaganda ideologica e mezzo per condizionare il comportamento individuale e collettivo" ${ }^{\text {. }}$

Afinal, segundo elucida Roger Griffin em Fixing Solutions: Fascist Temporalities as Remedies for Liquid Modernity - ensaio publicado em 2015 num volume do Journal of Modern European History dedicado ao tema Fascist Temporalities ${ }^{9}$ - ao perscrutar tais temporalidades peculiares do fascismo, emanantes do mito da eternidade da nação e da raça, “ $[\mathrm{m}]$ embers of the fascists' organic 'national community' were thus exhorted both overtly and subliminally to find a personal transcendent meaning and sense of heroic mission through their active participation in the process of national rebirth" ${ }^{10}$. Anuindo idêntica perspectiva, concomitantemente Harald Bodenschatz avalia no artigo inicial do livro Urbanism and Dictatorship: A European Perspective ${ }^{11}$, de 2015, Urbanism and

\footnotetext{
${ }^{5}$ PEGORIN, Elisa - "Architettura e regime tra Italia e Portogallo. Relazione nelle opere pubbliche dello Estado Novo". Estudos Italianos em Portugal. Lisboa: Instituto de Estudos Italianos. ISSN 0870-8584. Nova Série, N.o 12 (2017) p. 83-95.

${ }^{6}$ Neste caso específico, a autora refere-se directamente ao contributo de: TEOTÓNIO PEREIRA, Nuno; FERNANDES, José Manuel - "A Arquitectura do Fascismo em Portugal”. In PINTO, António Costa [et al.] - O Fascismo em Portugal: Actas do Colóquio. Lisboa: Regra do Jogo, 1982. p. 533-551.

${ }^{7}$ Op. cit., p. 85.

${ }^{8}$ Idem.

${ }^{9}$ Este número do Journal of Modern European History foi editado por Fernando Esposito, nele constando cinco artigos, para além do referido ensaio de Roger Griffin, que merecem a nossa referências. São eles: GRIFFIN, Roger - "Fixing Solutions: Fascist Temporalities as Remedies for Liquid Modernity”. Journal of Modern European History. München: C.H.Beck. ISSN (online) 1611-8944. Volume 13. N.o 1 (2015) p. 5-23; ESPOSITO, Fernando; REICHARDT, Sven - "Revolution and Eternity. Introductory Remarks on Fascist Temporalities”. Journal of Modern European History. München: C.H.Beck. ISSN (online) 1611-8944. Volume 13, No 1 (2015) p. 24-43; ARTHURS, Joshua - "The Excavatory Intervention: Archaeology and the Chronopolitics of Roman Antiquity in Fascist Italy". Journal of Modern European History. München: C.H.Beck. ISSN (online) 1611-8944. Volume 13, No 1 (2015) p. 44-58; BEN-GHIAT, Ruth - "The Imperial Moment in Fascist Cinema”. Journal of Modern European History. München: C.H.Beck. ISSN (online) 1611-8944. Volume 13, No 1 (2015) p. 59-78; CARSTOCEA, Raul - "Breaking the Teeth of Time: Mythical Time and the 'Terror of History' in the Rhetoric of the Legionary Movement in Interwar Romania”. Journal of Modern European History. München: C.H.Beck. ISSN (online) 1611-8944. Volume 13, No 1 (2015) p. 79-97; FOGU, Claudio - "The Fascist Stylisation of Time". Journal of Modern European History. München: C.H.Beck. ISSN (online) 1611-8944. Volume 13, No 1 (2015) p. 98-114.

${ }^{10}$ Op. cit., p. 23.

${ }^{11}$ Realçam-se nesta publicação os textos de: BODENSCHATZ, Harald - "Urbanism and Dictatorship: Expanding Spaces for Thought!”. In BODENSCHATZ, Harald; SASSI, Piero; WELSH GUERRA, Max - Urbanism and Dictatorship: A European Perspective. Basel: Birkhäuser, 2015. ISBN 978-3-03821-690-2. p. 15-26; SEVILLA-BUITRAGO, Álvaro - "Urbanism and Dictatorship: Perspectives of the Field of Urban Studies”. In BODENSCHATZ, Harald; SASSI, Piero; WELSH GUERRA, Max - Urbanism and Dictatorship: A European Perspective. Basel: Birkhäuser, 2015. ISBN 978-3-03821-690-2. p. 27-35; BEESE, Christine - "Urbanism and Dictatorship: Perspectives of Art History". In BODENSCHATZ,
} 
Dictatorship: Expanding Spaces for Thought!, que, à margem do enviesamento próprio de uma via "Fascist, National Socialist, socialist or clerical-authoritarian", em geral "[a] dictatorship's sociopolitical project always focuses on the return to a great past and the promise of a great future" 12 . Em consequência, ao examinar os novos impérios erguidos durante a primeira metade de novecentos na Alemanha, Itália, Espanha, Portugal e ainda na União Soviética, Harald Bodenschatz conclui:

"[f] or dictatorships, the widespread approval of large design projects was an overarching goal, which limited experimentation with unpopular forms. Architecture and urban design were not only a means to demonstrate power, but also to fascinate, inspire, and build consensus. This required appropriate design and application. Therefore, form was not intended mainly to suppress the population, at least not within their own country. Nor was it only populist. It latched on to trusted, everyday features, while also trying to link these to the dictatorship. The appealing forms were intended to present

Harald; SASSI, Piero; WELSH GUERRA, Max - Urbanism and Dictatorship: A European Perspective. Basel: Birkhäuser, 2015. ISBN 978-3-03821-690-2. p. 36-42; SPIEGEL, Daniela - "Urbanism in Fascist Italy: All Well and Good?”. In BODENSCHATZ, Harald; SASSI, Piero; WELSH GUERRA, Max - Urbanism and Dictatorship: A European Perspective. Basel: Birkhäuser, 2015. ISBN 978-3-03821-690-2. p. 43-58; CREMASCHI, Marco; ERNESTI, Giulio - "Probing the Region: Plans for Rome during the 1930s". In BODENSCHATZ, Harald; SASSI, Piero; WELSH GUERRA, Max - Urbanism and Dictatorship: A European Perspective. Basel: Birkhäuser, 2015. ISBN 978-3-03821-690-2. p. 59-74; CIACCI, Leonardo - "The Role of Newsreels in the Modernization of Cities: More than just Propaganda". In BODENSCHATZ, Harald; SASSI, Piero; WELSH GUERRA, Max - Urbanism and Dictatorship: A European Perspective. Basel: Birkhäuser, 2015. ISBN 978-3-03821-690-2. p. 75-88; CANTO MONIZ, Gonçalo; OPPEN, Christian von - "Urbanism under Salazar: Program, Practice, and Reception". In BODENSCHATZ, Harald; SASSI, Piero; WELSH GUERRA, Max - Urbanism and Dictatorship: A European Perspective. Basel: Birkhäuser, 2015. ISBN 978-3-03821-690-2. p. 89-101; OPPEN, Christian von - "Urbanism: The Driving Force and Stage of the Portuguese Dictatorship". In BODENSCHATZ, Harald; SASSI, Piero; WELSH GUERRA, Max - Urbanism and Dictatorship: A European Perspective. Basel: Birkhäuser, 2015. ISBN 978-3-03821-690-2. p. 102-116; SAMBRICIO, Carlos - "On Urbanism in the Early Years of Francoism”. In BODENSCHATZ, Harald; SASSI, Piero; WELSH GUERRA, Max - Urbanism and Dictatorship: A European Perspective. Basel: Birkhäuser, 2015. ISBN 978-3-03821-690-2. p. 117-134; PABLO, Ainhoa Díez de - "Preservation of Franco's Social Housing Estates in Madrid". In BODENSCHATZ, Harald; SASSI, Piero; WELSH GUERRA, Max - Urbanism and Dictatorship: A European Perspective. Basel: Birkhäuser, 2015. ISBN 978-3-03821-690-2. p. 135-147; HARLANDER, Tilman - "Urbanism and Housing Policy in Nazi Germany: A Commentary”. In BODENSCHATZ, Harald; SASSI, Piero; WELSH GUERRA, Max - Urbanism and Dictatorship: A European Perspective. Basel: Birkhäuser, 2015. ISBN 978-3-03821-690-2. p. 148-165; SCHEFFLER, Tanja - "The Technical Fairground in Leipzig in the Period of National Socialism”. In BODENSCHATZ, Harald; SASSI, Piero; WELSH GUERRA, Max - Urbanism and Dictatorship: A European Perspective. Basel: Birkhäuser, 2015. ISBN 978-3-03821-690-2. p. 166-182; BODENSCHATZ, Harald; FLIERL, Thomas - "Controversial Urbanism During the First Years of the Stalin Dictatorship”. In BODENSCHATZ, Harald; SASSI, Piero; WELSH GUERRA, Max Urbanism and Dictatorship: A European Perspective. Basel: Birkhäuser, 2015. ISBN 978-3-03821-690-2. p. 183-198; FLIERL, Thomas - "Ernst May's Standardized Cities for Western Siberia”. In BODENSCHATZ, Harald; SASSI, Piero; WELSH GUERRA, Max - Urbanism and Dictatorship: A European Perspective. Basel: Birkhäuser, 2015. ISBN 978-3-03821-690-2. p. 199-216; WELSH GUERRA, Max - "Urbanism, Dictatorship and Historiography: A Contextualization”. In BODENSCHATZ, Harald; SASSI, Piero; WELSH GUERRA, Max - Urbanism and Dictatorship: A European Perspective. Basel: Birkhäuser, 2015. ISBN 978-3-03821-690-2. p. 217-228.

${ }^{12}$ Op. cit., p. 23. 
the efforts to modernize the nation in a positive manner. Form was also not only meant for show, but also benefited the social groups that profited from the regime's policy"13.

Diante deste quadro singular, pretende-se comprovar em Paisagem e Monumentos de Portugal: Images do Ressurgimento Nacional a tese de que um significativo conjunto de feiçóes arquitectónicas identificadas com o projecto de Oliveira Salazar já se achava plasmado em diferentes lugares do País, pouco tempo antes da eclosão da 2. ${ }^{a}$ Guerra Mundial. Trata-se de um legado que por hoje, crê-se, sobrevive disperso em muitas das nossas cidades e paisagens. Para tanto, recorreremos sobretudo à análise de três ediçóes patrocinadas pela propaganda nacional que foram publicadas entre os anos de 1939 e de 1943 - Images Portugaises ${ }^{14}$, Paisagem e Monumentos de Portugal ${ }^{15}$ e Obras Públicas: Caderno do Ressurgimento Nacional ${ }^{16}$-, não excluindo outras com elas relacionadas.

Por conseguinte, como aquilata Harald Bodenschatz, confia-se que uma perspectiva meramente histórica das ditaduras europeias deve ser superada, pois "[o] ur dealing with dictatorships is an expression of the current culture of memory and ability to recognize old and new forms of dictatorship" ${ }^{17}$. Embora não seja objectivo explícito do trabalho, não deixaremos porém de questionar, resumidamente, nas consideraçóes finais o papel da contemporaneidade. Compulsando um dos artigos que serve de conclusão ao livro Urbanism and Dictatorship: A European Perspective - Urbanism, Dictatorship and Historiography: A Contextualization -, da autoria de Max Welsh Guerra, fica para nós evidente que, entre demais interrogaçóes ou possibilidades de investigação, importa à historiografia ajuizar "the relationship between the specific ways in which dictatorships tried to solve certain problems through urbanism [and architecture], which had also been approached by other dictatorial or parliamentarian-democratic systems by applying urbanism's [and architecture's] methods"18.

\section{História, fonte de riqueza e poesia}

Em sintonia com os princípios nacionalistas e ruralistas preceituados pelo Estado Novo, a viagem preparada pelo SPN, ao que se julga em 1939, exibe Portugal como uma rara e original "fèerie des contrastes" 19 . Como nota Ema Cláudia Pires ${ }^{20}$, em Images Portugaises fabrica-se metodicamente uma narrativa em redor de certas dicotomias que têm por objectivo celebrar a obra multifacetada realizada por Oliveira Salazar. Assim, a pretexto da história de Portugal e dos monumentos, realçando antagonismos como 'vida no campo versus vida na cidade' e 'arte popular versus arte erudita',

${ }^{13}$ Idem.

${ }^{14}$ SPN - Images Portugaises. Lisboa: Ediçôes SPN, [1939]. s.i..

${ }^{15}$ SANTOS, Luiz Reis; QUEIROZ, Carlos - Paisagem e Monumentos de Portugal. Lisboa: Edição da Secção de Propaganda e Recepção da Comissão Nacional dos Centenários, 1940.

${ }^{16}$ SPN - Obras Públicas: Cadernos do Ressurgimento Nacional. Lisboa: Ediçóes SPN, [1943].

${ }^{17}$ Op. cit., p. 24.

${ }^{18}$ Op. cit., p. 226.

${ }^{19}$ FERRO, António - "[Prefácio]”. In SPN - Images Portugaises. Lisboa: Ediçốes SPN, [1939]. s.i..

${ }^{20}$ PIRES, Ema Cláudia - O Baile do Turismo. Turismo e Propaganda no Estado Novo. Casal de Cambra: Caleidoscópio, 2003. 125 p. ISBN 9728801025. 
propagandeia-se a via de regeneração perfilhada: a reconciliação entre passado e presente e entre tradição e progresso, num caminho que encerra em si mesmo a necessidade de domesticação de todas as convicções e doutrinas discordantes das instituídas. Se de início se exprimia um desejo de continuidade, afinal tal programa subentendia uma antítese entre o antes da Revoluçáo Nacional e a modernidade internacionalista que, em todo o caso, ia florindo em nome do progresso apregoado. Depois de elaborar para consumo interno o álbum Portugal 1934, no desfecho da década de trinta António Ferro veria por fim publicado um retrato de Portugal condizente com o seu projecto e com o imaginário salazarista. Em apenas sessenta e três singelas figuras e precisas legendas compunha a antologia de todas as paisagens e realidades portuguesas. Porque a obra de restauração material, restauração moral e restauração nacional se encontrava nesta época em fase dita de engrandecimento, verifica-se que, em francês e em inglês, se procurava primeiramente revelar o que nós fizemos em detrimento da máxima o que eles não fizeram (os políticos da 1. a República, entenda-se).

$\mathrm{Na}$ prática, os destinatários desta colectânea votada a certas Images Portugaises eram aqueles que, pouco ou nada se preocupando com o quotidiano da política e economia nacionais, ao invés, se encantavam com os monumentos pátrios e o pitoresco das nossas paisagens e gentes. Vem a propósito recordar o artigo Os Monumentos (II) que, em 1838, Alexandre Herculano originariamente publicou na revista O Panorama: Jornal litterário e instructivo da Sociedade Propagadora dos Conhecimentos Úteis:

"Calculae quantos viajantes terão atravessado Portugal neste seculo. De certo que não vieram cá para correrem nas nossas commodas diligencias pelas nossas bellas estradas, ou navegarem nos nossos rapidos vapores pelos nossos amplos canaes; de certo que náo vieram para aprenderem a agricultar com os nossos agricultores, nem a fabricar com os nossos fabricantes; mas para admirarem os mosteiros da batalha, de Alcobaça e de Belem, a sé velha de Coimbra, a cathedral, a igreja de S. Francisco e o templo romano de Evora, a matriz de Caminha e a collegiada de Guimarães, os castellos da Feira e de Almourol, e enfim, tantas obras primas de architectura que encerra este cantinho do mundo" ${ }^{21}$.

Denunciando a "incuria aggressiva" e a "raiva assoladora" com que a generalidade dos portugueses de oitocentos, em "nome do progresso", arbitrava e condenava, sem "distincção nem juízo, o mau e o bom de eras antigas", Alexandre Herculano expunha que eram de facto os turistas estrangeiros quem melhor compreendia e apreciava as "antiguidades do nosso paiz", isto é, sentia o "valor dos monumentos da arte e da história" 22 nacionais.

Não obstante tal circunstância, era ininteligível que essas "admiraveis aggregações de marmore ou de granito" não fossem apreciadas internamente como uma potencial fonte de riqueza, porque numa época aprazada pela economia política, a "sciencia do nosso tempo", os monumentos poderiam converter-se num "capital productivo" quando a "arte ou os factos historicos os torna[ssem] recommendaveis", aquilatava, indagando

${ }^{21}$ HeRCUlAnO, Alexandre - Opúsculos: Questóes Públicas. Tomo II. Lisboa: Viúva Bertrand, 1873. p. 31-32.

${ }^{22}$ Ibidem, p. 30-31. 
os simpatizantes do camartelo se criam que esses "romeiros da arte" voltavam a casa sem despender "muito ouro" 23 . "E falaes de economia politica, e anniquilaes o capital dos monumentos" 24 , contestava Alexandre Herculano, defendendo que os monumentos constituíam, antes de tudo, uma fonte de patriotismo, qual fonte de poesia.

Desde logo, este desígnio de propensão nacionalista foi explicitamente retratado no artigo A Arquitectura Gothica. Igreja do Carmo em Lisboa, que Alexandre Herculano deu à estampa nas páginas do primeiro número da revista $O$ Panorama, em 6 de Maio de 1837. De acordo com Lúcia Rosas, nesta crónica estabelecem-se alguns dos tópicos fundamentais que conduziram à "consagração do monumento histórico em Portugal", à "valorização dos edifícios góticos, apesar da imprecisão cronológica e artística sobre o estilo", e à "exaltação da época correspondente" 25 . Representando um evidente elogio à arquitectura gótica, este texto igualmente náo deixa de ser um inédito protesto contra o descuido a que o Governo e os municípios haviam votado certos e "antigos edifícios nacionaes", cuja unidade funcional e formal Alexandre Herculano salvaguardava, face ao indistinto uso de elementos próprios de outros sistemas, quais fossem: "estuques", "dourados" e "madeiras entalhadas com ridículo máu-gosto"26.

Assim, tomando como exemplo o ministério das instituiçôes oficiais em Inglaterra e França, Alexandre Herculano apelaria ao Governo e às municipalidades nacionais que vigiassem, preservassem e reparassem o que ainda restava dos "monumentos de estylo gothico",

“[...] que são como a historia da intelligencia e da grandeza do paiz, e que talvez em breve seráo modelo para os artificies, quando de todo acabar o preconceito de que em artes só grego e o romano é bello; quando se persuadirem que os habitos, as opiniōes, e as crenças de uma naçáo devem estar em harmonia com os seus monumentos" ${ }^{27}$.

Alexandre Herculano distinguiu nos monumentos pátrios especialmente três valores: o histórico, o artístico e o nacional. À luz da proposição que nasceu com a crença do romantismo nos caracteres nacionais, o volksgeist, glorificou a "arquitectura da Idade Média contra a hegemonia clássica", instituiu a concordância entre a "arquitectura gótica e a história de Portugal" e compreendeu os "monumentos na idiossincrasia da nação", explica, por sua vez, Lúcia Rosas expondo outros dois pontos que reproduzem a importante acção desenvolvida por Alexandre Herculano em favor da consagração do dito monumento histórico em Portugal: "Apela à conservação dos edifícios porque as 'pedras falam', são testemunhas e herança do passado"; e "A conservação do passado também se justifica em nome da instrução" 28 .

${ }^{23}$ Ibidem, p. 31-32.

${ }^{24}$ Ibidem, p. 32.

${ }^{25}$ ROSAS, Lúcia - Monumentos Pátrios: A arquitectura religiosa medieval - património e restauro (1835-1928). Tese de Doutoramento. Porto: Faculdade de Letras da Universidade do Porto, 1995. p. 17.

${ }^{26}$ HERCULANO, Alexandre - "A Architectura Gothica". O Panorama: Jornal Litterário e Instructivo da Sociedade Propagadora dos Conhecimentos Úteis. Vol. 1. N.o 1 (1837) p. 2.

${ }^{27} \mathrm{Idem}$.

${ }^{28}$ Op. cit., p. 22-23. 
O próprio Alexandre Herculano alegaria, em crónica publicada na edição de 8 de Junho de 1843 da Revista Universal Lisbonense: Jornal dos interesses physicos, moraes e litterarios por uma sociedade estudiosa, a respeito de A Eschóla Polytechnica e o Monumento: Conhecimentos Uteis, que a condição de um qualquer monumento existir é o lembrar. "Essencialmente é só isto": um "meio de transmitir ao futuro uma lembrança do passado", enfatizava, defendendo que uma "geração não pertence unicamente a si, pertence ao preterito cuja herdeira é, ao futuro, cuja testadora será" 29 .

Através da intervenção directa de outras figuras da cena nacional, esta tese ganharia protagonismo crescente no decurso do século XIX, vindo mesmo a influenciar a acção do regime político que por um mais longo espaço de tempo deteve a superintendência dos monumentos durante a centúria subsequente: o Estado Novo. Dada a importância documental destes objectos arquitectónicos para a História e para a Arte, ser-lhes-ia então reconhecida uma função didáctica que implicava a exaltação de determinadas épocas, sobretudo a Idade Média e os Descobrimentos, e a evocação dos méritos das reformas políticas, sociais e culturais consumadas no decurso desse período.

Sempre que o presente se revelava impreciso e instável, os monumentos, persistentes no fluir do tempo, viriam a ser deliberadamente instrumentalizados para legitimar novos projectos políticos, já que possibilitavam forjar um percurso, retrospectivo, ordenado e autêntico, de um passado que se pretendia primitivo e imperturbável. Mesmo quando se alertava para o mau estado de algum monumento, encontrava-se subjacente a ideia de que proteger este património material e imaterial era garantir o futuro da nação.

Credor dos princípios românticos de Victor Hugo, Alexandre Herculano entendeu a noção de monumento histórico como um livro de pedra, numa lógica de herança total que compreende todos os vestígios materiais resultantes da acção do homem e, por essa razão, são passíveis de serem investidos numa determinada funcionalidade histórica e memorial. Neste sentido, escrevia na supradita crónica publicada na Revista Universal Lisbonense que "o livro e o templo, o obelisco e a estatua, o palacio e a campa" e, igualmente, "a arvore e até o chão defeso e condemnado a perpetua esterilidade podem ser monumentos" 30 .

A convicção de que as construçóes do passado eram documentos portadores de um significado identitário - ideia de nacionalidade - implicou o alargamento do conceito de monumento e o permanente sublinhar do seu valor cognitivo, com a consequente não-distinção entre monumento histórico e monumento comemorativo. Conquanto esta não-distinção originasse interpretaçóes diversas, os monumentos foram considerados, desde meados do século xIx ao início do século xx, testemunhos irrepetíveis da história e depositários de valores de carácter específico e transversal a todas as categorias sociais, permitindo aceder a múltiplos saberes que iam da política aos costumes, das artes às técnicas, entre outros. Durante este intervalo de tempo, o valor cognitivo do monumento histórico esteve, por conseguinte, direccionado para este conjunto de conhecimentos, extrapolando o campo da História da Arte, e passando,

${ }^{29}$ HERCULANO, Alexandre - "A Eschóla Polytechnica e o Monumento: Conhecimentos Uteis". Revista Universal Lisbonense: Jornal dos interesses physicos, moraes e litterarios por uma sociedade estudiosa. Vol. 2, N.o 38 (1843) p. 470-471.

${ }^{30}$ Ibidem, p. 470. 
também, a ilustrar o sentimento nacional. Foi a importância atribuída aos monumentos enquanto valores nacionais que levou Alexandre Herculano a não os distinguir entre não-intencionais e intencionais.

Desde o primeiro artigo que divulgou no jornal O Panorama até ao final dos anos sessenta do século, o título monumento histórico foi comummente aplicado a todos os testemunhos materiais do passado, levando a equiparar, entre demais exemplos, edifícios antigos a registos escritos, a utensílios domésticos ou, ainda, a jóias. Só nesta altura a concepção alargada de monumento histórico, que incluía quaisquer objectos passíveis de transmitir experiências do antanho, conheceria um significado ajustado em exclusivo ao construído, enquanto conjunto de imóveis de interesse histórico, artístico e estético. A este conceito veio associar-se a locução monumento nacional, cuja relação se anteviu primeiramente na obra Monumentos Nacionaes de José Mendes Leal, em 1868, e, mais tarde, em 1886, em Monumentos de Portugal: Históricos, Artisticos e Archeologicos, da autoria de Ignacio de Vilhena Barbosa.

Numa breve nota sobre estes dois registos, podemos adiantar que o de José Mendes Leal sobreveio na transição entre as explanaçóes de Alexandre Herculano e um período subsequente mais proficiente em estudos, medidas e acçóes de natureza legislativa do poder político entáo instituído, a monarquia constitucional. Embora unicamente tenham reconhecido edifícios como monumentos nacionais, os dois autores não apresentam as razóes que os levaram a perfilhar tal critério. Contudo, de acordo com as orientaçóes de Alexandre Herculano, Ignacio de Vilhena Barbosa considerava que a arquitectura era o meio privilegiado para se chegar ao passado, centrando assim no património construído a história e a memória que determinavam a qualificação de um objecto arquitectónico como monumento nacional.

Como esclarece Rute Figueiredo, a "relação entre a arquitectura e a sociedade" não constituía uma novidade à época do escrito de Ignacio de Vilhena Barbosa, na medida em que o espírito desta ligação sobreviera com a "estética romântica" ${ }^{1}$ dos anos trinta e quarenta de oitocentos. Em concreto, advoga a autora que tal correspondência ocorreu pela mão de Alexandre Herculano, que mais seguramente situava a "introdução de um novo conceito de 'monumento', associado não apenas à ideia de longa duração, mas, antes, à sua inscrição na noção de 'documento', testemunho das circunstâncias políticas, sociais e culturais de um tempo" 32 . Todavia, perante o desfilar das teorias positivistas e evolucionistas e o crescendo dos nacionalismos, na "vertente de uma perspectiva anti-decadentista", Ignacio de Vilhena Barbosa entendia a arquitectura segundo uma "lógica organicista" e "mecanicista" que tinha latente um princípio de estilo gravado na "noção de transformação" 33.

Entendendo que os períodos artísticos se fundamentavam numa sucessão de etapas - começo, desenvolvimento, perfeição e decadência -, Ignacio de Vilhena Barbosa concebia a evolução estética dos estilos como um "processo de transformação

${ }^{31}$ FIGUEIREDO, Rute - Arquitectura e Discurso Crítico em Portugal (1893-1918). Tese de Mestrado. Lisboa: Faculdade de Ciências Sociais e Humanas da Universidade Nova de Lisboa, 2002. p. 95.

${ }^{32}$ Idem.

${ }^{33}$ Idem. 
biológico"34, em harmonia com a percepção que Johann Joachim Winckelmann, em 1764, divulgou na obra Geschichte der Kunst des Alterthums. Neste quadro, não só a arquitectura, como também os monumentos, tinham as suas idades, sendo a transição entre estilos operada de acordo com as transformaçóes da vida social. Por seu lado, baseando-se no diploma que esteve na origem da criação do Conselho de Monumentos Nacionais, um Decreto de 24 de Outubro de 1901, Gabriel Pereira considerava em A Architectura Portugueza: Revista Mensal da Arte Architectural Antiga e Moderna, edição de Março de 1908, que a locução Monumentos Nacionaes se achava indubitavelmente associada aos imóveis revestindo interesse nacional histórico, arqueológico e artístico. Segundo investigámos, ainda assim não existem referências que, de modo cabal, expliquem a passagem do conceito lato de monumento histórico, reivindicado por Alexandre Herculano, para a concepção restrita de José Mendes Leal, nem, mais directamente, para a de Gabriel Pereira.

Para o Estado, a distinção ficou resolvida com a publicação entre 1906 e 1910, por sucessivos decretos, dos monumentos classificados como nacionais, confirmando-se a concessão do título apenas ao património imóvel, o que a legislação republicana relativa à organização dos serviços artísticos e arqueológicos do novo regime viria a certificar no ano de 1911 - Decretos n. ${ }^{\text {os }} 1$ e 2 de 26 de Maio de 1911, do Governo Provisório da República Portuguesa (Diário do Governo de 29 de Maio de 1911). A partir de então, o valor nacional constituía formalmente o primeiro dos critérios de classificação, desde logo legitimando os demais, de que era indissociável.

A valorização de um sentimento pátrio que se identificava e logo se reproduzia nos monumentos nacionais, ideia que sobremaneira se sobrepôs à correlativa materialização artística, decorria, como se expôs, desde Alexandre Herculano. Contudo, de igual modo caracterizava a produção e a discussão teórica, bem como as diversas posiçôes sociais, políticas e culturais assumidas durante grande parte dos séculos XIX e XX. Assim, ao longo da Ditadura dirigida por Oliveira Salazar, os monumentos foram reiteradamente considerados nacionais porque contribuíam para fazer, afirmar e consolidar uma certa história da nação, revelando a antiguidade e as qualidades dos antepassados em todas as suas dimensões. Na memória A Política dos Monumentos, apresentada na Associação dos Arqueólogos Portugueses a 30 de Junho de 1921, Luís Chaves retratou, de forma ímpar, este estado de espírito e, a respeito da sua classificação, entendia:

“[...] o que é bello, não basta. Mesmo essa noção era fallivel, quando aplicada principalmente a uma obra de arte, em que a relatividade fosse affastada e longinqua. Tem de se ligar ao criterio da classificaçáo o conceito da relatividade historica. Quanto signifique para a naçáo uma prova da sua existencia por padróes, que a balisem na sua historia, na sua indole, e quanto lhe indique a ancestralidade geradora do que, por facilidade de nomenclatura, se chama raça portuguêsa, deve ser considerado monumento nacional, pois á nação respeita" ${ }^{35}$.

\footnotetext{
${ }^{34}$ Idem.

${ }^{35}$ CHAVES, Luís - "A Política dos Monumentos". Arqueologia e História. Vol. 1 (1922) p. 76.
} 
Além de antecipar o pensamento político que iria imperar nas décadas subsequentes acerca do significado dos monumentos nacionais, esta tese revelava, em concomitância com o alargar do conhecimento historiográfico, que as estruturas religiosas e militares medievais se constituíam os principais objectos de classificação, em grande medida dado o seu prévio carácter documental.

Embora à partida a propriedade individual per se não justificasse a sua protecção legal, a conotação positiva que os imóveis românicos e góticos apresentavam tornou-se motivo suficiente, num espírito de colecção, para a sua classificação, como a aludida memória de Luís Chaves também comprova:

"O trabalho inicial não pode ser outro senão enunciar a lista ou serie geral dos monumentos a classificar sob este aspecto, de forma que nos varios e successivos capitulos do cadastro sejam incluidos todos que da respectiva rubrica se conheçam, e de futuro se acrescentem quantos vão posteriormente apparecendo" 36 .

Esta normalização tornar-se-ia preponderante por o entendimento de um certo imóvel como elo de uma cadeia de valor histórico, arqueológico e artístico ser garantia bastante para o desenvolvimento de intervençóes de conservaçáo ou de restauro, por analogia.

A reprodução de elementos formais integrantes de um mesmo hipotético sistema gramatical ajudaria à restituição do imóvel ao seu estado original, o primitivo, e, deste modo, à sua condição documental e monumental. Neste contexto, os castelos, enquanto construçóes da época medieval, viram sobretudo o seu perfil arquitectónico ser alvo de um crescente processo de valorização e instrumentalizaçáo que conduziu à sua maciça classificação e, em simultâneo, a uma não menos relevante campanha de obras operada no Estado Novo. Assim o provámos no trabalho dedicado aos Castelos em Portugal ${ }^{7}$.

Em síntese, reconhecemos que a vocação determinista da arquitectura vingou em Portugal desde os primeiros manifestos de oitocentos e perdurou durante um largo período de tempo, apesar dos distintos propósitos que revestiram as mudanças políticas sociais e culturais que assinalaram a história portuguesa destes dois séculos, o XIX e Xx.

\section{Arquitectura, instrumento do governo}

Na secção precedente, procurámos resumidamente expor, invocando determinados escritos de Alexandre Herculano, como se processou o despertar de uma consciência patrimonial que percorreu em continuidade, asseguraríamos, os tempos da Monarquia Constitucional, da 1. a República e da Ditadura. Sobretudo, pretendemos retratar como a presença dos monumentos no território e nas suas diferentes paisagens se manifestou questão de raiz nacionalista, directamente confrontada com uma vontade explícita de refundação e reconstrução da identidade de ser português.

De facto, a um conjunto de imóveis, identificados como testemunho de um passado heróico, atribuiu-se influente conotação de índole política, como ocorreu no decurso da

${ }^{36}$ Idem.

${ }^{37}$ Op. cit.. 
governação de Oliveira Salazar. A título de exemplo, revisitando as edições de $O$ Século Ilustrado divulgadas a 27 de Maio de 1939 e a 15 de Junho de 1940, confirma-se que os monumentos, no caso, os castelos, eram contemplados como veros retratos identitários do ser colectivo nacional, pois afiguravam-se como As Pedras Sagradas de Portugal e os Simbolos da Pátria. Dessarte o comprovava a legenda da fotografia inaugural do dito álbum Images Portugaises, exibindo uma cruz, em primeiro plano, e a colina do Castelo de Sesimbra, como pano de fundo, que pretensamente desvelava, entre o real e a ficção, um país de conto de fadas no desfecho dos anos trinta: "Les chateaux forts et la croix, signes éternels. L'indépendance et la foi présidèrent et présideront toujours aux destinées du Portugal" 38 .

O interesse e a utilidade conferidos pelo Estado Novo à 'Païsagem e Monumentos de Portugal' foram de igual forma corroborados pelo SPN no primeiro número da revista Panorama, publicado em Junho de 1941. A propósito, nele era citado o prefácio de Luiz Reis Santos na edição homónima de 1940, a cargo da Secção de Propaganda e Recepção da Comissão Nacional dos Centenários. Aí se mencionava que o genuíno retrato do País somente se vislumbraria no "“culto consciencioso pelo território continental da Pátria e pelos testemunhos arquitectónicos de instituiçôes e factos que glorificaram a Nação, quer na beleza e valor morais e plásticos, quer nos aspectos geomorfológicos, históricos e artísticos"”39.

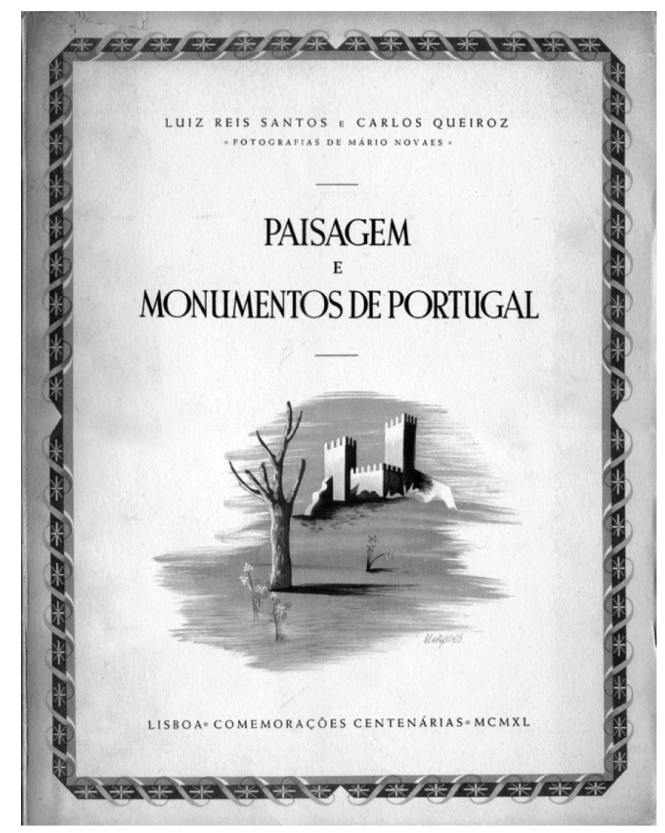

Figura 1: Capa do livro Paisagem e Monumentos de Portugal, 1940.

\footnotetext{
${ }^{38}$ SPN - Images Portugaises. Lisboa: Ediçôes SPN, [1939]. s.i..

${ }^{39}$ SPN - "Païsagem e Monumentos de Portugal". Panorama: Revista Portuguesa de Arte e Turismo. N.o 1 (1941) p. 20.
} 
Uma vez mais, à semelhança do que sucede em dois cartazes de A Lição de Salazar, a imagem de um alegado castelo modelo na capa do livro dos centenários (figura 1) - isolado no topo de uma colina, cujas numerosas torres e distintas muralhas recortadas por ameias se apresentavam primitivamente reconstituídas - simbolizava o ambicionado espírito da Nação, propalado tanto pelo Presidente do Conselho quanto pelo director da propaganda nacional. Isto é, anunciava a exposição de uma grande montra panorâmica de paisagens risonhas, escalvadas, suaves, humanas... fundamentada no ressurgimento político, económico e moral empreendido pelo salazarismo. Como sabemos, tratava-se de um projecto pessoal tecido ao abrigo de certos valores da tradição e da história que, alegadamente, a terra portuguesa sempre poderia testemunhar e autenticar.

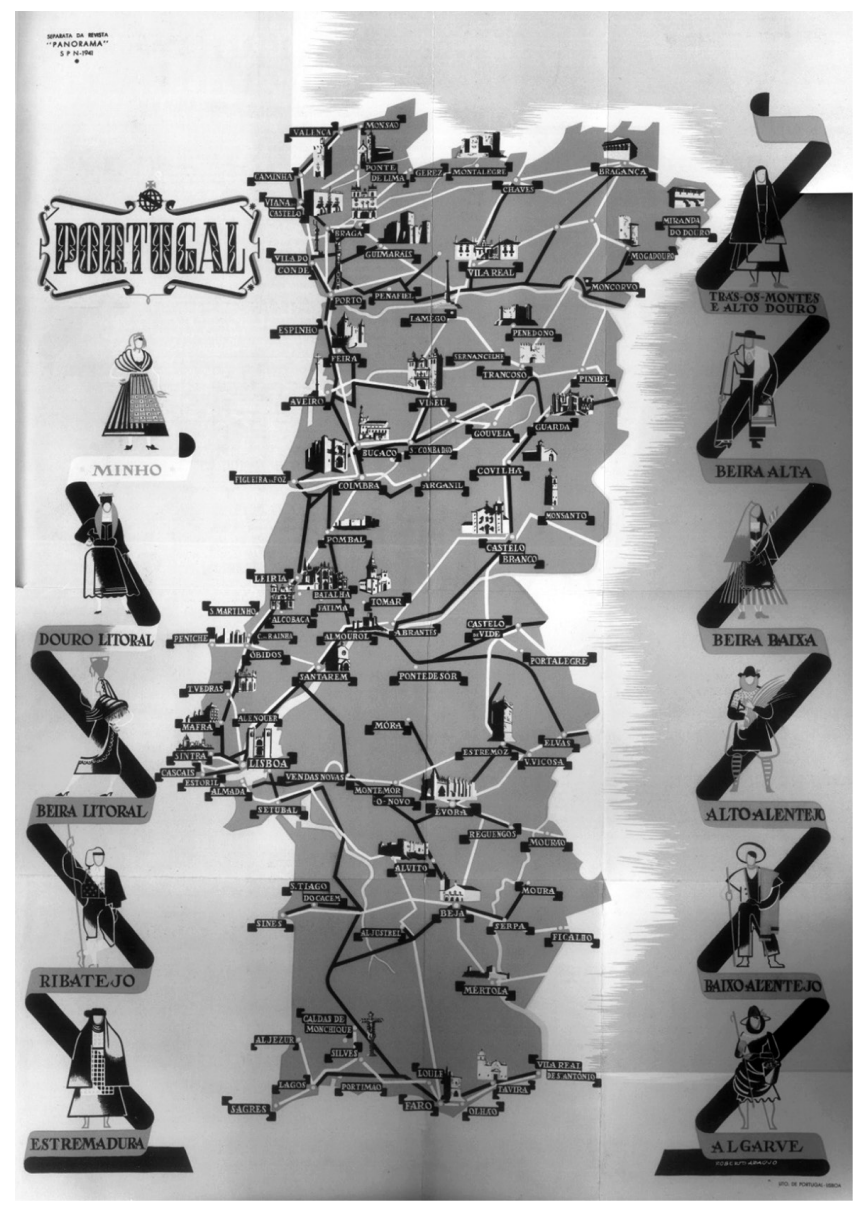

Figura 2: Mapa de Portugal. Separata publicada na edição de Junho de 1941 da revista Panorama.

Tal percepção da Pátria salazarista descortina-se, por exemplo, na separata da revista Panorama dada à estampa pelo SPN em edição de Junho de 1941. Aí, lobriga-se não só 
um Portugal Monumental e Histórico determinado por um conjunto de monumentos dispersos por todo o território, mas, em simultâneo, um Portugal Tradicional e Popular autenticado pelos trajes folclóricos típicos de cada uma das onze províncias continentais portuguesas (figura 2).

Ao património material acresce a herança imaterial retratada pela peculiar vida do campo, onde os homens ainda tiram o "chapéu e [dão] os bons-dias ao viandante menos apressado, sem lhe pedir nada em troca”, como descreve Carlos Queiroz no capítulo que dedicou à "Paisagem" 40 na obra Paisagem e Monumentos de Portugal, publicada em co-autoria com Luiz Reis Santos, que, por seu lado, se encarregou dos "Monumentos" 41. Fazendo jus ao Mapa de Portugal impresso na Revista Portuguesa de Arte e Turismo, o segundo destes autores comprovava que, do Minho e de Trás-os-Montes ao Algarve e do litoral atlântico à fronteira com Espanha, eram os "castelos e as igrejas, os conventos e os solares, os fortes, as pontes e os aquedutos, os cruzeiros e os pelourinhos" que por certo melhor lembravam e solenizavam, na sua "estática mudez", as "páginas brilhantes da nossa história, factos passados" ${ }^{42}$. Num horizonte de 800 anos de independência e, a propósito, recordando $O$ Culto da Arte em Portugal de Ramalho Ortigáo, publicado no ano de 1896, Luiz Reis Santos conclui que o "conhecimento da vida pública e privada, individual e colectiva da gente portuguesa, da sua organização política e social, das suas crenças religiosas e dos seus feitos guerreiros", tão-só se poderia (re)apreender através da "expressão artística" e do "significado histórico" que cada um dos "Monumentos Nacionais e Imoveis de Interêsse Público classificados até Setembro de 1940” expunha nas "rústicas paisagens e nos aglomerados urbanos", evidenciando, em ambientes apropriados, "notas pitorescas de grande valor ornamental, principalmente sugestivas da sensibilidade e do espírito, das tradiçôes e dos ideais do povo" ${ }^{43}$. Realçando que uma larga maioria das "nossas relíquias arquitectónicas" até àquele momento havia sido salva "graças aos trabalhos proficientes de beneficiação e restauro levados a efeito pelo Estado", sobretudo devido à "notabilíssima obra reconstrutiva” realizada pelos serviços da Direcção-Geral dos Edifícios e Monumentos Nacionais, vulgo DGEMN, Luiz Reis Santos anuía aos monumentos "qualquer coisa superior" que deveria encher de orgulho e encantar os portugueses: "traços comuns de pensamento e sentimento, que imprimem, à mais colectiva de tôdas as artes, uma expressão inconfundível de consciência, de fôrça e de unidade nacional" ${ }^{44}$. Com base em diversas referências bibliográficas, declarava:

"Os monumentos de arte prehistórica, as ruínas romanas, os edifícios visigóticos, as relíquias árabes e moçárabes, e os primeiros templos da veneração cristã, esclarecem-nos acêrca das populaçôes que ocuparam o nosso território continental antes da fundação da Monarquia. As construçóes civis e militares, os palácios, as tôrres e os castelos medievais,

\footnotetext{
${ }^{40}$ SANTOS, Luiz Reis; QUEIROZ, Carlos - Paisagem e Monumentos de Portugal. Lisboa: Edição da Secção de Propaganda e Recepção da Comissão Nacional dos Centenários, 1940. p. 7.

${ }^{41}$ Ibidem, p. 33.

${ }^{42}$ Idem.

${ }^{43}$ Ibidem, p. 33 e 70.

${ }^{44}$ Ibidem, p. 33-34.
} 
as capelas, as igrejas e as catedrais românicas e góticas, explicam as origens da Nação Portuguesa, a sua razão de ser, a sua verdadeira missão europeia, a consolidação nacional e os factores que influiram no movimento gerador dos descobrimentos e conquistas, para a dilatação da fé cristã e do império de Deus. As edificaçóes manuelinas e renascentistas, barocas e rocòcós, neo-clássicas e contemporâneas, definem os impulsos da expansão portuguesa, em palpitante linguagem plástica, a atitude de Portugal perante a história

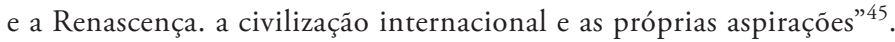

Mas, se a restituição à "beleza sóbria do plano primitivo" de um extenso conjunto de modelos da História de Portugal, confiada aos técnicos da DGEMN, era, por um lado, responsável pela renascença de muitas pedras sagradas outrora arruinadas e adulteradas no "solo pátrio", fruto de "duras provas do Tempo, da intolerância e da inconsciência humanas", por outro, também traduzia as "feiçôes íntimas da alma portuguesa" 46 que o projecto do salazarismo pretendia concretizar. Logo, no começo da década de quarenta, a conservação e o restauro dos monumentos desempenhavam um papel inconfundível na consolidação e inculcação dos princípios e realizaçóes do regime. No entanto, como historia o autor, a "arquitectura monumental" ${ }^{47}$ dos anos trinta excedeu o difícil trabalho de restabelecimento dos monumentos nacionais.

Depois de a arquitectura portuguesa dos vinte e cinco anos inaugurais do século $\mathrm{xx}$ manifestar sobremodo o "mundo confuso" do legado identitário do século precedente e "o definhamento das instituïçóes, da consciência e das actividades nacionais, certos aspectos da desorganização social" de então, a do último decénio passou a ser "bem o reflexo das grandes aspiraçóes e reformas duma nação que renasc[ia] e progred[ia]", oferecendo ao povo o "espectáculo deslumbrante do seu glorioso passado e das suas grandes possibilidades actuais” ${ }^{48}$, constata Luiz Reis Santos.

Herdeiros, entre outras figuras, do "espírito racional" de Miguel Ventura Terra, do "precursor nacionalista" Raul Lino que se propôs, de acordo com o plano de Afonso Lopes Vieira, “'reaportuguesar Portugal tornando-o europeu” e dos “sólidos princípios académicos” ${ }^{49}$ proporcionados pelos professores José Luís Monteiro e José Marques da Silva em Lisboa e no Porto, respectivamente, os arquitectos Porfírio Pardal Monteiro, Carlos Ramos, Cristino da Silva, Cottinelli Telmo, Jorge Segurado, Gonçalo de Mello Breyner, Paulino Montez, Couto Martins, Veloso Reis, Miguel Jacobetty Rosa, Luís Benavente, Raúl Tojal, Adelino Nunes, Rodrigues Lima e Francisco Keil do Amaral afiguravam-se à época da instituição e da consolidação da Ditadura, de acordo com Luiz Reis Santos, como os principais intérpretes de uma nova orientação que defendia os desejos e possibilidades do presente moderno internacional... em comunhão estilística com os modelos regionalistas e nacionalistas apregoados nas liçóes de Oliveira Salazar.

Num momento assinalado pelo discurso da restauração material, restauraçáo moral e restauração nacional, conviveram na terra portuguesa, dentro do plano de realizaçóes

\footnotetext{
${ }^{45}$ Idem.

${ }^{46}$ Ibidem, p. 33 e 51.

${ }^{47}$ Ibidem, p. 69.

${ }^{48}$ Ibidem, p. 68-69.

${ }^{49}$ Ibidem, p. 69.
} 
programadas pelo regime, obras com retratos díspares, uns afeiçoados às emergentes correntes internacionalistas, outros antecipando um fazer nacional à moda salazarista. Era, com certeza, um legado tão "extenso e profundo" ${ }^{50}$ quanto multiforme, que Luiz Reis Santos sintetizava enumerando alguns projectos e obras, iniciados ou concluídos, sob a administração de Oliveira Salazar, a saber: Instituto Superior Técnico, Instituto Nacional de Estatística e Estaçóes Marítimas, em Lisboa, da autoria de Porfírio Pardal Monteiro; Instituto do Cancro, em Lisboa, de Carlos Ramos; Liceu de Coimbra, de Carlos Ramos, Jorge Segurado e Adelino Nunes; Liceu Nacional de Jacinto de Matos, em Beja, de Cristino da Silva; Liceu de Lamego, Sanatório da Covilhã, Edifícios dos Caminhos de Ferro, Cadeias Comarcãs e traçado e Fonte Monumental da Praça do Império, em Belém, de Cottinelli Telmo; Liceu de Filipa de Lencastre e Casa da Moeda, em Lisboa, de Jorge Segurado; Escola Naval no Alfeite, dos irmáos Rebelo de Andrade; Estádio Nacional, de Miguel Jacobetty Rosa; Correios e Telégrafos, em diversos locais, de Adelino Nunes; Igreja de Nossa Senhora de Fátima, em Lisboa, de Porfírio Pardal Monteiro (designaçôes dos projectos/obras condizentes com as indicaçôes do autor).

No preâmbulo de Paisagem e Monumentos de Portugal, álbum repleto de fotografias de Mário Novaes e de "trechos evocadores e descritivos" informados do testemunho insuspeito de vários autores de referência e, ainda, do préstimo de instituiçóes oficiais como a Direcção-Geral dos Serviços Florestais e Aqüicolas e a incontornável DGEMN, Luiz Reis Santos pretendeu com certa objectividade, diríamos, "descrever e agrupar os principais monumentos existentes no País, desde o periodo de ocupação romana até aos nossos dias", caracterizando com particular acuidade os mais representativos das "épocas, por todos os títulos gloriosas, da Consolidação Política da Pátria e dos Descobrimentos e Conquistas" ${ }^{51}$. Da selecção e classificação feitas, depreendia que por "afinidades de estilo e seqüencias nos movimentos estéticos" se explicavam as "linhas evolutivas da arquitectura portuguesa e, conseqüentemente, as caracteristicas do génio artístico nacional" 52 . Esta constituía, em definitivo, uma perspectiva determinista que, do mesmo modo, validava e justificava as dissemelhantes intervençóes executadas sob a jurisdição técnica e autoridade moral do Governo da Ditadura.

Assim se entende Luiz Reis Santos quando, ao citar o simbólico projecto de Porfírio Pardal Monteiro para a Igreja de Nossa Senhora de Fátima, em Lisboa, concebia que no percurso da arquitectura do programa salazarista coabitavam uma "linguagem plástica", próxima da ideologia instituída, e expressóes internacionalistas, experimentadas à data, com raízes sobrevindas das históricas "virtudes colectivas da Pátria" ${ }^{3}$. Mais não eram, afinal, do que "destinos superiores" que, desde as lendárias batalhas travadas contra infiéis ou vizinhos peninsulares à sombra de castelos erguidos ou reconstruídos nos longínquos séculos XII e XIII, sempre haviam revelado o "caminho para a glorificação de Portugal" 54 , crê o autor.

\footnotetext{
${ }^{50}$ Idem.

${ }^{51}$ Ibidem, p. 5.

${ }^{52}$ Idem.

${ }^{53}$ Ibidem, p. 69.

${ }^{54}$ Idem.
} 
Resgatando o significado que Fernando Rosas assentiu a dois dos "mitos ideológicos fundadores do Estado Novo", o "palingenético" e o da "essência ontológica do regime", podemos testemunhar que a arquitectura da regeneração promovida pelo Presidente do Conselho foi aceite como um indispensável e influente meio de afirmação do "novo nacionalismo", comprometido com imagens visivelmente opostas, embora imbuídas de idêntico propósito: a legitimaçáo dos princípios celebrados a preceito da ambicionada reconquista do "verdadeiro e genuíno curso da história pátria" que se pressentia, em especial, na imaginada feição primitiva dos símbolos da "institucionalização do destino nacional" e da "materialização política" de legítima e impoluta "essencialidade histórica portuguesa mítica" ${ }^{5}$, os monumentos nacionais.

De par com a reintegração de um vasto número de castelos, sés, igrejas, conventos e mosteiros, também a edificação moderna e regionalista de bairros de casas económicas, escolas primárias e liceus, entre demais obras públicas, caracterizava esse tal Portugal Novo providencialista, revisto pela própria Ditadura como um somatório de modelos díspares, todavia emparelhados e dialogantes entre si. De tal sorte se compóe o álbum Images Portugaises, numa narrativa que a priori subentende a unidade da obra à laia do aforismo oficial do Estado Novo: Nada contra a Nação, tudo pela Nação.

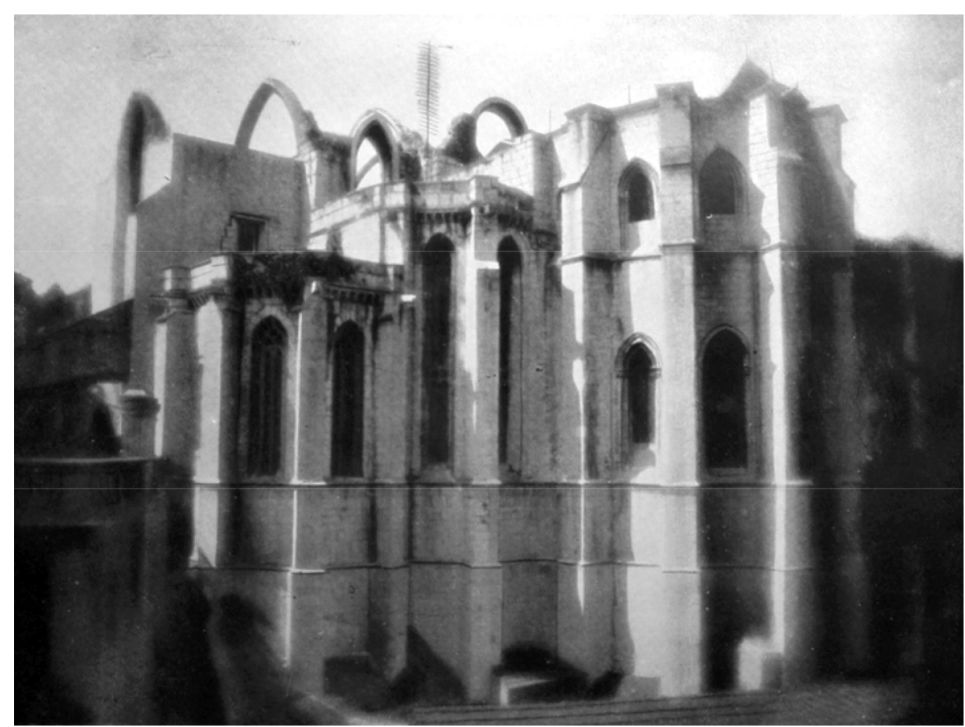

Figura 3: Ruínas da Igreja do Carmo, Images Portugaises, ca. 1939.

${ }^{55}$ ROSAS, Fernando - Salazar e o Poder: A Arte de Saber Durar. Lisboa: Ediçōes Tinta-da-China, 2012. ISBN 9789896711405 . p. 321 e 323. 


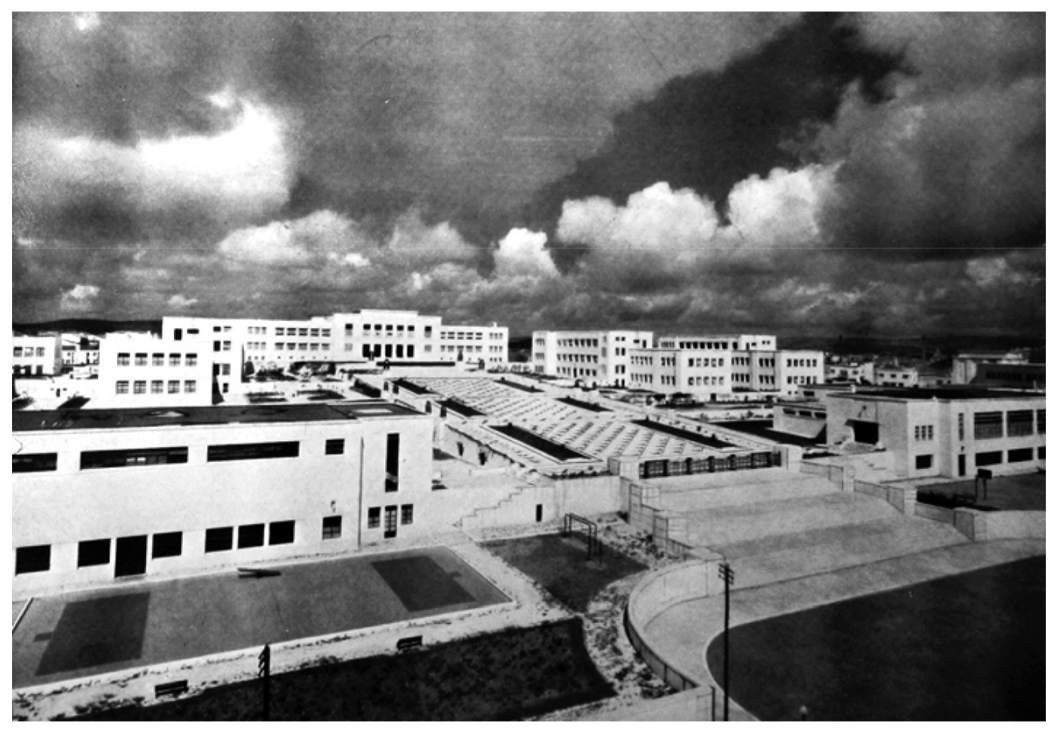

Figura 4: Instituto Superior Técnico, Images Portugaises, ca. 1939.

Como se lê nas páginas do referido catálogo de imagens do quotidiano nacional, no final dos anos trinta sentia-se que a Nação se encontrava finalmente restaurada e em franco engrandecimento graças ao seu líder Oliveira Salazar. Com base numa fotografia e respectiva legenda aí patenteadas, afiançaríamos, de modo figurado, que Portugal se convertera num “'nouveau cadeau de Salazar au peuple portugais'...", num teatro do povo e para o povo, onde se confrontavam e equiparavam, sem a distância aconselhada, "la somptuosité architectural du Monastère de Batalha [...] aux lignes modernes de l'Église de Notre Dame de Fatima”, "Les ruines vénérables du Carmo [aux] bâtiments modernes de l'Institute Supérieur Technique" ${ }^{66}$ (figuras 3 e 4) ou, ainda, o jovem Liceu de Beja à velha Universidade de Coimbra. De igual forma, postos lado a lado os retratos de um bairro em Lisboa e das obras do novel Porto de Leixóes, pretendia-se provar que a acção governativa mantinha preservadas as tradiçóes nacionais e, ao mesmo tempo, acompanhava de perto os progressos da técnica, na convicção de que a recém-criada mocidade portuguesa seria fiel depositária de tal escola de disciplina e fé patriótica.

\section{Obras Públicas, legado do salazarismo}

Poucos anos volvidos, num "dramático momento da História [Mundial]", observando as realizaçóes e as "Consequências económicas e perspectivas" dos vários planos de Obras Públicas, o SPN reiterava este objectivo, assegurando que qualquer que fosse o rumo económico, político e social resultante do conflito bélico, a "obra de fomento e de apetrechamento" produzida pelo regime havia de perseverar e progredir em perfeita "obediência a uma doutrina" assente num "corpo de princípios jurídicos, morais e

\footnotetext{
${ }^{56}$ Op. cit., s.i..
} 
filosóficos" que visavam reintegrar Portugal na "linha das suas tradiçốes históricas" Por outras palavras, as ediçóes SPN atestavam, com recurso a este balanço de natureza propagandística, que na base da restauração material do País se achava inevitavelmente uma politica de verdade, uma politica de sacrifício e uma politica nacional, cuja defesa económica, defesa moral, defesa política e protecção dos interesses da Naçáo chefiada por Oliveira Salazar se manifestavam não só nas grandiosas obras de modernização de infra-estruturas que promoviam a melhoria das condiçôes de vida mas, também, nas diligências levadas a cabo no campo social e cultural, as designadas obras do espirito.

Fazendo jus ao "memorável discurso" 58 que o Presidente do Conselho proferiu em 25 de Junho de 1942 aos microfones da Emissora Nacional sobre as supracitadas defesas, recordava-se que a conturbada época vivida decorria fortemente vincada pelo "tríplice signo da autoridade, do trabalho e da preocupação social", e que, em caso algum "Nenhuma Nação se pod[ia] eximir à autoridade forte; nenhum homem ao dever do trabalho; nenhuma actividade ou riqueza ao critério da sua utilidade social" 59 . Logo, se como primeira premissa se impunha "sermos em tudo nós e não outros [para] não nos confundirmos", como segunda, prevenia Oliveira Salazar, a doutrina e a obra política, no "mais alto sentido em que se possa[m] tomar", deviam aspirar ao desígnio maior de garantir junto dos "homens os meios materiais e condiçôes para a sua vida moral", no duplo intento da sua unidade e personalidade, da "coesão que faz a força e do carácter que a torna inconfundível entre as naçôes" ". Por defesa moral, o outrora Professor da Universidade de Coimbra compreendia a "defesa da consciência da Nação", de pronto reconhecendo que a prossecução desta empreitada tinha como propósito último a auto-determinação dos povos a qualquer momento - que não o do Império Português, seguramente - em funçáo do "interesse colectivo", e a possibilidade de dar "contribuição activa e útil à obra de civilizaçấo de que aproveita em comum a humanidade" ${ }^{\text {"1 }}$. Prescrito o plano de salvação da unidade moral da Nação, nesta longa comunicação radiodifundida, Oliveira Salazar aproveitava para elucidar os ouvintes dos resultados entretanto alcançados:

"Por disposição providencial e previdente acção política através de séculos, nós temos a felicidade rara de constituir na Europa uma unidade geográfica; possuímos a mesma língua; constituímos a mesma raça; professamos o mesmo credo, e temos uma só cultura. Sobre este conjunto de elementos coesos a unidade política é apenas corolário e cúpula natural, que não foi afectada pela expansão ultramarina e a constituição do Império: por toda a parte a Mãe-Pátria conseguiu imprimir a sua imagem, fixar caracteres fundamentais, de modo que não é artificiosa criação a unidade imperial. Obra admirável da natureza e da política dos antepassados, ninguém poderá acusar-nos de a não termos

${ }^{57}$ SPN - Obras Públicas: Cadernos do Ressurgimento Nacional. Lisboa: Ediçóes SPN, [1943]. p. 87, 89-90 e 93.

${ }^{58}$ Ibidem, p. 89

${ }^{59}$ OLIVEIRA SALAZAR, António - "Defesa económica - Defesa moral - Defesa política" (25 de Junho de 1942). In COIMBRA EDITORA (Ed.) - Discursos e notas politicas, Vol. III: 1938-1943. Coimbra: Coimbra Editora, 1944. p. 349.

${ }^{60}$ Ibidem, p. 322, 333 e 338.

${ }^{61}$ Ibidem, p. 333. 
desenvolvido e consolidado, criando-lhe novas bases materiais com a solidariedade económica e vivificando-a espiritualmente com profunda consciência nacionalista. Se esta obra repousa sobretudo na uniáo dos espíritos à volta do maior interesse nacional, e se a união dos espíritos, com ser reflexo da unidade pátria, é também a sua maior força e factor de engrandecimento, nenhum dever sobreleva hoje ao dever de defendê-la" ${ }^{32}$.

Recorramos agora a Os princípios e a obra da Revolução no momento interno e no momento internacional expostos por Oliveira Salazar em 27 de Abril de 1943, de novo na Emissora Nacional, e transcritos na edição Obras Públicas, atrás mencionada. Daí se respigava que, quando ao "lado da ponte ou da estrada", construídas para "comodidade dos povos", se contemplava o "castelo ou o monumento", a "pequena igreja secular ou o mosteiro abandonado", reintegrados na paisagem, era a materialização da política do Novo Estado que se presenciava, em defesa e apologia da "identidade do ser colectivo, reforçando a personalidade nacional" ${ }^{63}$. Neste contexto, arguia-se que as consequências económicas, sociais e culturais desta política eram já perceptíveis no início dos anos quarenta e anteviam-se perduráveis. Reflectiam-se directamente no quotidiano lusitano através da melhoria geral das condiçóes de vida e, em particular, da dupla reabilitação do espírito nacional: o de "Portugal no ânimo dos portugueses" e o dos "portugueses no concerto das Naçóes" ${ }^{\text {", }}$, como concluía Oliveira Salazar na prédica radiofónica.

Como aconteceu nos álbuns Portugal 1934, Images Portugaises e Portugal 1940, e mais tarde viria a suceder noutras ediçôes com a chancela dos SPN/SNI, também neste Caderno do Ressurgimento Nacional as fotografias cumpriam um papel decisivo quanto ao produto dos planos de Obras Públicas estabelecidos e, consequentemente, quanto ao desenvolvimento do superior intento do regime, o projecto do salazarismo. Com efeito, com a reprodução de um leque de retratos das paisagens portuguesas expressava-se o "cunho de seriedade e dignidade que tornou Portugal [desejadamente] respeitado em todo o Mundo" ". Além disso, esta ampla montra panorâmica conjuntamente ilustrava como a política de fomento executada se revelava em determinadas Obras Públicas, logo vistas como modelos de bem fazer. Ao fim e ao cabo, tratava-se de uma criteriosa selecção que, paradoxalmente, ou não, elegia como símbolos identitários do apetecido ressurgimento nacional tanto construções de feição nacional-regionalista e de natureza técnica como outras de impressão internacional-modernista.

2 Ibidem, p. 334-335.

${ }^{63}$ OLIVEIRA SALAZAR, António - "Os princípios e a obra da Revolução no momento interno e no momento internacional” (27 de Abril de 1943). In COIMBRA EDITORA (Ed.) - Discursos e notas politicas, Vol. III: 1938-1943. Coimbra: Coimbra Editora, 1944. p. 402-403.

${ }^{64}$ Ibidem, p. 404.

${ }^{65}$ Op. cit., p. 93. 


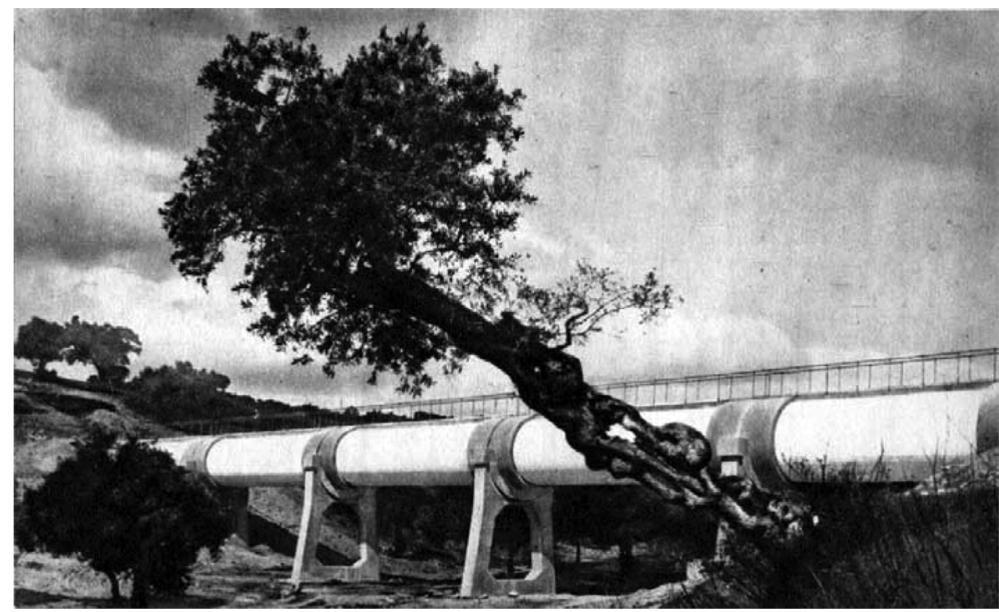

Figura 5: Conduta para abastecimento de água à cidade de Lisboa, Obras Públicas, ca. 1943.

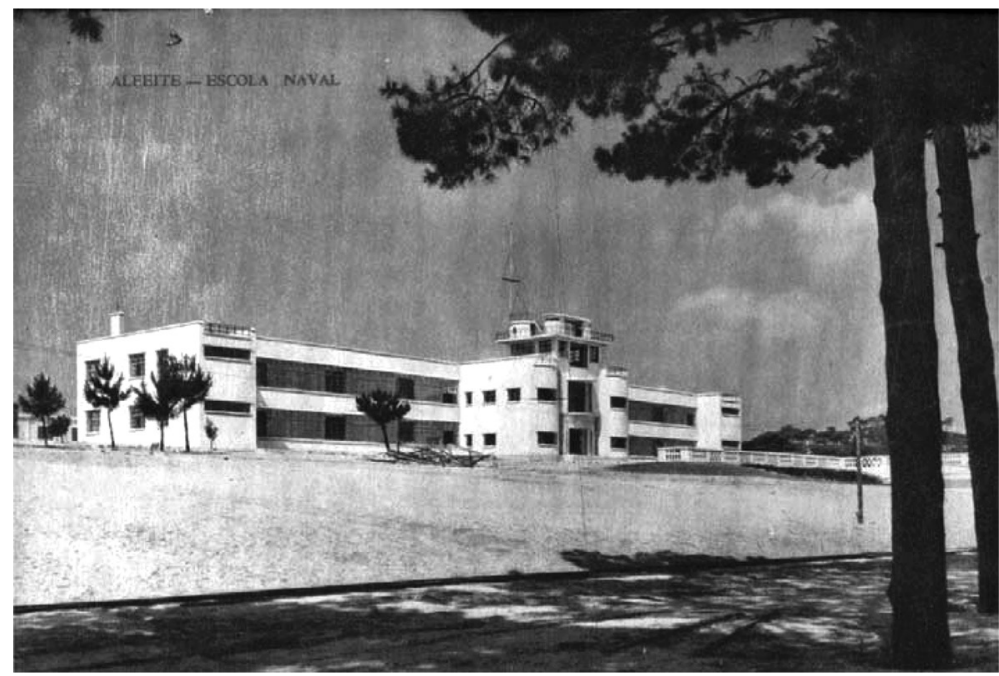

Figura 6: Escola Naval no Alfeite, Obras Públicas, ca. 1943. 


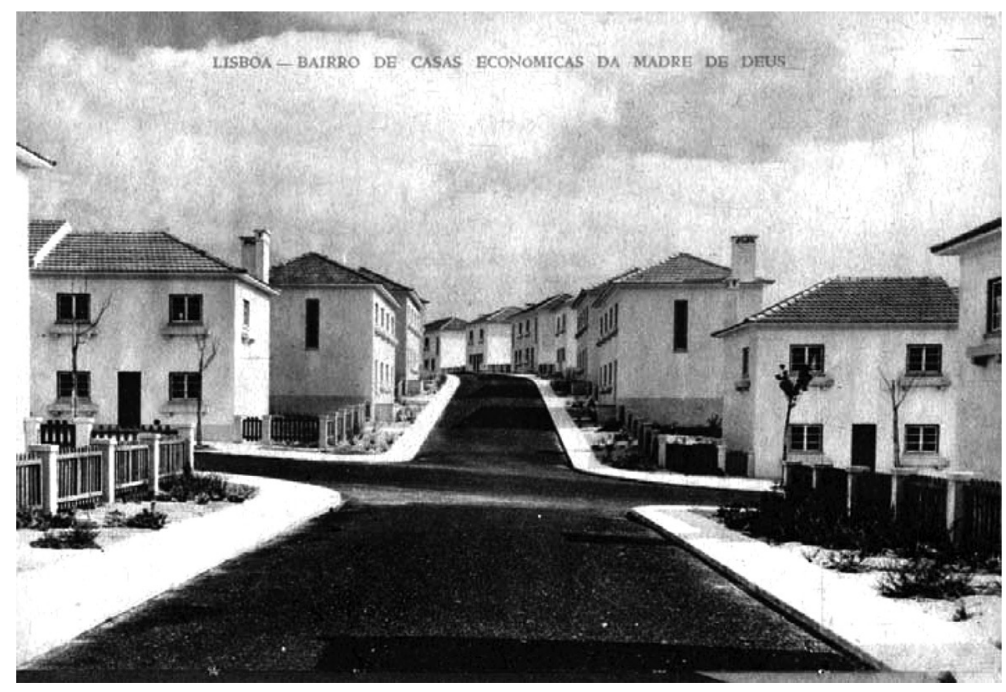

Figura 7: Bairro de Casas Económicas da Madre de Deus em Lisboa, Obras Públicas, ca. 1943.

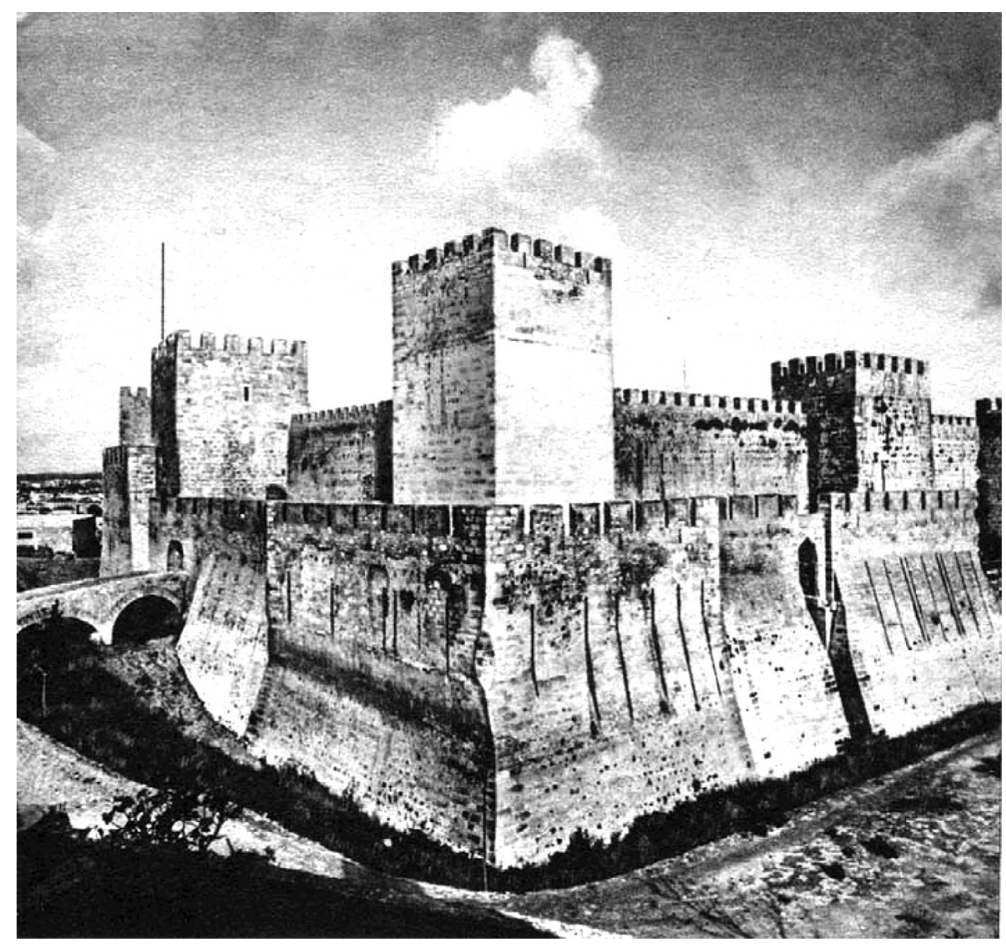

Figura 8: O Castelo de S. Jorge depois de restaurado pela DGEMN, Obras Públicas, ca. 1943. 
Após no livro Portugal 1934 se aferirem distintas linguagens arquitectónicas, como, por exemplo, as dos Liceus Nacionais Fialho de Almeida, Latino Coelho e Dr. Júlio Henriques, e na publicação Images Portugaises se equipararem, de forma premeditada, Mosteiro da Batalha e Igreja de Nossa Senhora de Fátima de Lisboa, Ruínas da Igreja do Carmo e Instituto Superior Técnico, Liceu de Beja e Universidade de Coimbra e um Bairro na capital e obras do Porto de Leixóes, neste Caderno sobre as Obras Públicas entreviam-se, lado a lado, uma conduta técnica para abastecimento de água (figura 5), a moderna Escola Naval no Alfeite (figura 6), de Carlos e Guilherme Rebelo de Andrade, o regionalista Bairro de Casas Económicas da Madre de Deus em Lisboa (figura 7), de Luís Benavente, e o restaurado Castelo de S. Jorge (figura 8), cujo aspecto primitivo há pouco tempo fora reavido pelos serviços técnicos da DGEMN. Entre outros casos que poderíamos expor, alguns deles amiúde publicados, observamos que os exemplos dados são suficientemente elucidativos para que se compreenda quão variado e multiforme se constituiu o legado do salazarismo. Como afirmaria o seu máximo obreiro na sessão de encerramento da exposição comemorativa dos Quinze Anos de Obras Públicas realizada no Instituto Superior Técnico, no dia 7 de Novembro de 1948, o volume de realizaçôes materiais era composto por "majestosos edifícios ou pequenas habitaçôes graciosas, de largas estradas e caminhos rústicos, de fábricas e de igrejas, de portos e de barragens, de escolas e de hospitais, de castelos e de quartéis", fruto de uma doutrina resolutamente aprazada pelo Governo e pela sociedade portuguesa:

"[...] uma sociedade hierarquizada sem privilégios, trabalhadora sem servidão, modesta sem miséria, progressiva sem despegar-se do passado de que se orgulha, colectividade em que o povo deixou de ser tropo da literatura política e não é mesmo uma classe, porque é aos nossos olhos a própria Nação" ${ }^{66}$.

Em comunhão com o "conceito preciso de Salazar", identificado em vários retratos da renovada realidade lusa, reconhecia-se, por fim, neste Caderno do Ressurgimento Nacional, que as consequências e perspectivas provindas da política de Obras Públicas se manifestavam com "efeitos imediatos e compensadores", por um lado, no "domínio puro da economia" ${ }^{67}$, por outro, mais influentemente nos campos social e cultural. Revelemos, então, como a propaganda nacional dirigida por António Ferro, a reboque de condutas de abastecimento de água, escolas, bairros de casas económicas e castelos reintegrados no território, garantia à Mãe-Pátria que o Portugal de Hoje e o Portugal de Amanhã eram, e seriam, com absoluta certeza, lugares melhores que aquele Portugal de Ontem, herdado da 1. a República. Nesse sentido, certificava-se:

“[...] pela execução de grandes obras de hidráulica agrícola, aumentando a productividade do nosso solo, contribuiu-se para a política do aumento geral da produção,

${ }^{66}$ OLIVEIRA SALAZAR, António - "No encerramento da Exposição de Obras Públicas" (7 de Novembro de 1948). In COIMBRA EDITORA (Ed.) - Discursos e notas politicas, Vol. IV: 1943-1950. Coimbra: Coimbra Editora, 1951. p. 342-343.

${ }^{67}$ Op. cit., p. $90-92$. 
fundamental sobretudo nos tempos de crise que atravessamos; pelo melhor e mais intenso aproveitamento das nossas quedas de água, fornecendo maiores quantidades de energia eléctrica e em melhores condiçóes de preço, torna-se possível a instalaçáo de algumas novas indústrias e o desenvolvimento das existentes; pela execução de grandes obras dos portos, que levaram ao aumento da sua freqüência e do correspondente tráfego, condicionaram-se, favorecendo-os, os movimentos da importação e da exportação; pela construção e conservação de uma boa rêde de estradas, permitiu-se o fácil e rápido escoamento da produção e o desenvolvimento do turismo; as obras de hidráulica geral, regularizando alguns cursos de água e protegendo as suas margens, e a dispersão, por todo o País, dum sem número de pequenas obras rurais (caminhos, arruamentos, captaçóes de água, electrificação rural, etc.), de interêsse restrito ou local; mas operando no conjunto e promovendo melhoria geral de comunicações, de sanidade e de condiçóes de vida -, são outros tantos elementos a influir favorávelmente na ecónomia geral da Nação"68.

Enaltecia-se ainda que, além destes efeitos económicos, a obra cumprida na vertente sócio-cultural alcançara resultados tão significativos quanto perenes, como:

“[...] a diminuïção do desemprêgo, com tôdas as suas favoráveis repercussões, pela absorção de milhares de braços na execução das obras; a diminuïçáo da mortalidade, determinada pelas numerosas pequenas e grandes obras de hidráulica urbana ou sanitária, operando melhores condiçóes de salubridade (abastecimento de água potável, esgôtos, etc.); a assistência médica e a protecção à mulher e à criança, tornadas possíveis, pela construção de hospitais e maternidades; pela construção de casas económicas, sob aquêle espírito económico, familiar e português, notàvelmente definido na magistral conferência proferida em 1934 pelo eminente estadista e Ministro das Obras Públicas e Comunicaçóes, Engenheiro Duarte Pacheco, resolve-se um problema de acentuado cunho social, relacionado com as classes médias e populares e interessando a solidariedade da família, a independência doméstica e a saúde física e espiritual do homem; pela construção de escolas primárias, dispende-se o esfôrço mais grandioso até hoje realizado em Portugal na luta contra o analfabetismo; pelo restauro de monumentos e edifícios, construção de museus, conservação dos palácios nacionais, acautelamos o nosso património artístico e monumental" ${ }^{69}$.

Seguramente, a amplitude das realizaçóes projectadas e construídas pelo regime teve francas consequências na vida das populaçóes, quer das que residiam na cidade, quer das que dia-a-dia labutavam e usufruíam a estimada felicidade do campo. Da renascença material conseguida, portugueses e aqueles que nos visitavam beneficiariam directa ou indirectamente, aproveitando a melhoria das várias vias de comunicação, da hidráulica, dos aproveitamentos hidroeléctricos, da rede de electrificação, do saneamento urbano e da alimentação de água potável às povoaçóes. De igual modo, usufruiriam da resoluçáo dos problemas de urbanização, dos melhoramentos rurais, da reparação dos

${ }^{68}$ Ibidem, p. $90-91$

${ }^{69}$ Ibidem, p. 91-92. 
edifícios e monumentos nacionais, assim como da construção de bairros económicos e de novos espaços para instalação de diferentes serviços públicos. Considerando as publicaçóes oficiais e oficiosas da época, de algumas das quais temos dado notícia no decurso deste trabalho, restam-nos poucas dúvidas em relação ao efectivo usufruto que a maioria dos portugueses experimentou com tal investimento do Estado, que o volume e a profusão territorial das obras produzidas ilustram.

Com Alexandre Alves Costa, diremos que a Arquitectura, a Cidade e o Território no Estado Novo constituíram, tal como a língua portuguesa, decisivos "factor[es] de coesão nacional", inigualáveis meios ao serviço da política que, usados contra uma "evidente tendência estrutural para a dissolução da Nação"70 , procuraram um novo espirito, uma distinta via, em certas circunstâncias históricas do passado e, naturalmente, do presente. De par com outras "construçōes identitárias" forjadas, por exemplo, com o milagre de Ourique, a reforma do "Império Cristão na continuidade da Reconquista", a "epopeia sintetizada nos Lusíadas", a jornada de regresso da "corte à aldeia do nacionalismo restauracionista", a independência contra franceses e ingleses e, contemporaneamente, com o "projecto de invenção de um "modelo português de socialismo"”, Alexandre Alves Costa constata que a Ditadura salazarista expressou, de forma explícita, o "nosso espírito ficcionista", "para amaciar a ironia, nossa veia poética", em prol de um projecto assente no "ruralismo clerical" que o poder político foi, e continua a ser, o principal responsável pela produção de projectos de (re)identificação nacional. Por esta razão, defende o autor de Identidade Nacional e Património Construído que, herdando um dissemelhante legado cultural, paisagístico e histórico, o Estado é, também, o "próprio fenómeno da nacionalidade"72, afirmando, sem dúvida, a sua doutrina n' O Sabor da Terra ${ }^{73}$.

Fazendo nossa a locuçáo de Alexandre Alves Costa, podemos reconhecer, dadas as circunstâncias nela aludidas, que no território português permanecem, ainda hoje, traços dos valores identitários estadonovistas. Decerto que na imagem do construído subjazem princípios políticos, planos de obras públicas e modelos paisagísticos, arquitectónicos e urbanos que estiveram na sua génese. Em suma, acreditamos que na terra que habitamos quotidianamente se descobre o legado do salazarismo.

\section{Considerações finais}

Observando a obra construída durante o período da Ditadura Nacional, não subsistem dúvidas quanto à política de representação entấo desenhada no território (assunto que sobremaneira ao artigo concerne) enquanto reflexo da ideologia autoritária e totalitária do sistema. Ao longo de mais de três décadas e meia, Oliveira Salazar conformou certa ideia, a sua, de identidade nacional: a terra portuguesa mais náo era

\footnotetext{
${ }^{70}$ COSTA, Alexandre Alves - "Identidade Nacional e Património Construído: Arquitectura, Cidade e Território”. ecdj.12 (2009) p. 53 e 55.

${ }^{71}$ Ibidem, p. 54.

${ }^{72}$ Ibidem, p. 56

${ }^{73}$ MATTOSO, José; DAVEAU, Suzanne; BELO, Duarte - Portugal: O Sabor da Terra. [Lisboa]: Círculo de Leitores / EXPO’98, 1997. 220 p. ISBN 972-42-1554-7.
} 
do que um raro sítio de fixaçáo e um adequado lugar de cumplicidade dos desígnios políticos vindos a gizar pelo regime desde 1932.

Mais de quarenta anos após o derrube do regime político do Estado Novo, a herança material procedente do projecto do antigo Professor da Universidade de Coimbra náo só sobrevive como pedra-de-toque da estrutura espacial, formal e funcional de diferentes ambientes urbanos ou paisagísticos, como persevera enquanto representante da cultura e identidade portuguesas. Monumentos nacionais, bairros de habitação social, estradas, pontes e edifícios diversos, como museus, cinemas, teatros, escolas primárias, liceus, universidades, hospitais, etc., restaurados ou erguidos sob a direcção do Ministério das Obras Públicas e de outros organismos do Estado Novo, constituem memória do longo ciclo estadonovista e, ao mesmo tempo, apreciáveis meios de referência do que se cogita ser português. Este panorama permanece hoje, à contrecoeur do que se podia imaginar perante a perda de autonomia indiciada pelos inflexíveis ditames de austeridade prescritos por troikas internacionais (e não só).

Não pretendendo centrar a discussão em torno desta questão, consideramos não ser despiciendo reflectir sobre o papel que pedras antigas e estruturas recentes - grosso modo, a organização do território - cumprem no quotidiano nacional. Assim conduzido, o debate pode porventura envolver temas como a influência que Deus e os outros elementos da trilogia salazarista, Família e Pátria, desempenham na conformação de uma nova Portugalidade democrática, compatível com a história de Portugal. Neste sentido, impóe-se avaliar as consequências da Revolução de Abril, concretamente eventuais impactos originados pela mudança de regime, na configuraçáo do território.

Conforme testemunhámos, a arquitectura do poder praticada à época do Fascismo em Portugal veio a consagrar um retrato do território convergente com o discurso reinante, com as suas políticas e com a sua presumida boa moral. À laia do Decálogo do Estado Novo, editado em 1934, exigia-se A Vanguarda do Nacionalismo Português ${ }^{74}$. $\mathrm{Na}$ realidade, tratava-se de um panorama da terra circunscrito às verdades e certezas consentidas pelo Presidente do Conselho. Oliveira Salazar somente aquiescia aos seus compatriotas uma Pátria enraizada nos feitos lendários de seus ilustres antepassados e na honradez vivida no campo em oposição à devassidão experimentada nas cidades modernas. Resumindo: numa incondicional crença em Deus, o País via-se reduzido às inconfundíveis feiçôes vivenciadas no recôndito Portugalzinho do Vimieiro.

Porém, o legado da Ditadura compreendeu, outrossim, obras de índole dissemelhante das oficialmente ditadas, a saber: obras modernas. Em qualquer dos casos, monumentos nacionais e nova arquitectura, como demais artes, técnicas e ofícios, converter-se-iam em importante meio de memorização dos anseios reivindicados pelo regime: tradição versus progresso. No entanto, crê-se que não se poderá afiançar que singular argumento não emanou de um plano antecipadamente celebrado para um futuro a longo prazo.

E hoje, que estratégia? Como esta interrogação, outras afins podem suscitar a nossa atenção, algumas das quais se elencam, a título de exemplo. 1) Pode garantir-se que a nova Portugalidade conquistada em Abril de 1974 se veio de facto a cumprir? 2) Por outras palavras: o Portugal de 2018 é consequência do Portugal de 1974? 3) No plano que aqui mais nos importa: será que a arquitectura retomou a sua verdadeira

\footnotetext{
${ }^{74}$ AMEAL, João - Decálogo do Estado Novo. Lisboa: Ediçōes SPN, 1934. 94 p.
} 
autonomia disciplinar, lavrando no território a anunciada democratização do espaço? 4) Em última instância: a arquitectura em democracia está, como é justo, a ser cuidada como vector essencial e responsável pela memorização da política no território?

Para dilucidar estas perguntas, resulta impreterível uma reflexão, para a elaboração da qual é pertinente convocar "argumentos de ordem histórica, que possam ajudar a perspectivar as bases, mais ou menos profundas, da circunstância contemporânea" 75 , conforme apresentou José António Bandeirinha na abertura da Conferência Arquitecto Marques da Silva 2014, dedicada à Arquitectura: A praça da autonomia, pedagogia, epistemologia, pensamento crítico. Uma análise da situação vigente reivindicará por certo a criteriosa exposição de relaçóes e exemplos em outras paragens, não sejamos nós, portugueses, cúmplices de um mundo globalizado ${ }^{76}$. Mas, como pressente Diogo Seixas Lopes a fechar a obra Melancolia e Arquitectura em Aldo Rossi, caberá à história e à teoria ter de "lidar com a incerteza acerca das circunstâncias de crises passadas e presentes" 77 . Corroborando tais palavras, afirmaremos, por último, que se esta "situação pode levar à dúvida", de igual modo ela "pode originar acção" 78 , como resposta a muitas das questóes levantadas.

Referências Bibliográficas

AMEAL, João - Decálogo do Estado Novo. Lisboa: Ediçōes SPN, 1934. 94 p.

ARTHURS, Joshua - "The Excavatory Intervention: Archaeology and the Chronopolitics of Roman Antiquity in Fascist Italy". Journal of Modern European History. München: C.H.Beck. ISSN (online) 1611-8944. Volume 13, N. ${ }^{\circ} 1$ (2015) p. 44-58.

AURELI, Pier Vittorio - Il progetto dell'autonomia: Politica e architettura dentro e contro il capitalismo. Macerata: Quodlibet, 2016. 192 p. ISBN 9788874628155.

BANDEIRINHA, José António - Arquitectura: A praça da autonomia, pedagogia, epistemologia, pensamento crítico. Porto: Fundação Instituto Arquitecto José Marques da Silva, 2017. 40 p. ISBN 978-989-97966-9-0.

BARBOSA, Ignacio de Vilhena - Monumentos de Portugal: Históricos, Artisticos e Archeologicos. Lisboa: Castro Irmão, 1886. 500 p.

BEN-GHIAT, Ruth - "The Imperial Moment in Fascist Cinema". Journal of Modern European History. München: C.H.Beck. ISSN (online) 1611-8944. Volume 13. N.o 1 (2015) p. 59-78.

BEESE, Christine - "Urbanism and Dictatorship: Perspectives of Art History". In BODENSCHATZ, Harald; SASSI, Piero; WELSH GUERRA, Max - Urbanism and Dictatorship: A European Perspective. Basel: Birkhäuser, 2015. ISBN 978-3-03821-690-2. p. 36-42.

${ }^{75}$ BANDEIRINHA, José António - Arquitectura: A praça da autonomia, pedagogia, epistemologia, pensamento crítico. Porto: Fundação Instituto Arquitecto José Marques da Silva, 2017. ISBN 978-989-97966-9-0. p. 5.

${ }^{76}$ Sobre este assunto, constitui referência: AURELI, Pier Vittorio - Il progetto dell'autonomia: Politica e architettura dentro e contro il capitalismo. Macerata: Quodlibet, 2016. 192 p. ISBN 9788874628155.

${ }^{77}$ SEIXAS LOPES, Diogo - Melancolia e Arquitectura em Aldo Rossi. Trad. Jorge Colaço. Lisboa: Orfeu Negro, 2016. ISBN 978-989-8327-83-3. p. 305.

${ }^{78} \mathrm{Idem}$. 
BODENSCHATZ, Harald - "Urbanism and Dictatorship: Expanding Spaces for Thought!". In BODENSCHATZ, Harald; SASSI, Piero; WELSH GUERRA, Max - Urbanism and Dictatorship: A European Perspective. Basel: Birkhäuser, 2015. ISBN 978-3-03821-690-2. p. 15-26.

BODENSCHATZ, Harald; FLIERL, Thomas - "Controversial Urbanism During the First Years of the Stalin Dictatorship”. In BODENSCHATZ, Harald; SASSI, Piero; WELSH GUERRA, Max - Urbanism and Dictatorship: A European Perspective. Basel: Birkhäuser, 2015. ISBN 978-3-03821-690-2. p. 183-198.

CANTO MONIZ, Gonçalo; OPPEN, Christian von - "Urbanism under Salazar: Program, Practice, and Reception". In BODENSCHATZ, Harald; SASSI, Piero; WELSH GUERRA, Max - Urbanism and Dictatorship: A European Perspective. Basel: Birkhäuser, 2015. ISBN 978-3-03821-690-2. p. 89-101.

CARSTOCEA, Raul - "Breaking the Teeth of Time: Mythical Time and the "Terror of History' in the Rhetoric of the Legionary Movement in Interwar Romania". Journal of Modern European History. München: C.H.Beck. ISSN (online) 1611-8944. Volume 13, N. ${ }^{\circ} 1$ (2015) p. 79-97.

CEC/SPN - Portugal 1940. Lisboa: CEC/Ediçôes SPN, [1940]. 107 p.

CHAVES, Luís - “A Política dos Monumentos”. Arqueologia e História. Vol. 1 (1922) p. 76-83.

CIACCI, Leonardo - "The Role of Newsreels in the Modernization of Cities: More than just Propaganda”. In BODENSCHATZ, Harald; SASSI, Piero; WELSH GUERRA, Max - Urbanism and Dictatorship: A European Perspective. Basel: Birkhäuser, 2015. ISBN 978-3-03821-690-2. p. 75-88.

CORREIA, Luís Miguel - "Il Duce à secretária de Salazar. Lição sobre o lugar da história no Nuovo Stato". Estudos Italianos em Portugal. Lisboa: Instituto de Estudos Italianos. ISSN 0870-8584. Nova Série, N. 12 (2017) p. 69-82.

CORREIA, Luís Miguel - Castelos em Portugal: Retrato do seu perfil arquitectónico [1509-1949]. 2. a ed. Coimbra: Imprensa da Universidade de Coimbra, 2011. 475 p. ISBN 9789892600604.

COSTA, Alexandre Alves - "Identidade Nacional e Património Construído: Arquitectura, Cidade e Território”. ecdj.12 (2009) p. 53-58.

CREMASCHI, Marco; ERNESTI, Giulio - "Probing the Region: Plans for Rome during the 1930s". In BODENSCHATZ, Harald; SASSI, Piero; WELSH GUERRA, Max - Urbanism and Dictatorship: A European Perspective. Basel: Birkhäuser, 2015. ISBN 978-3-03821-690-2. p. 59-74.

ESPOSITO, Fernando; REICHARDT, Sven - "Revolution and Eternity. Introductory Remarks on Fascist Temporalities". Journal of Modern European History. München: C.H.Beck. ISSN (online) 1611-8944. Volume 13, N.o 1 (2015) p. 24-43.

FERRO, António - “[Prefácio]”. In SPN - Images Portugaises. Lisboa: Edições SPN, [1939]. s.i.

FIGUEIREDO, Rute - Arquitectura e Discurso Crítico em Portugal (1893-1918). Tese de Mestrado. Lisboa: Faculdade de Ciências Sociais e Humanas da Universidade Nova de Lisboa, 2002.

FLIERL, Thomas - "Ernst May's Standardized Cities for Western Siberia”. In BODENSCHATZ, Harald; SASSI, Piero; WELSH GUERRA, Max - Urbanism and Dictatorship: A European Perspective. Basel: Birkhäuser, 2015. ISBN 978-3-03821-690-2. p. 199-216.

FOGU, Claudio - "The Fascist Stylisation of Time". Journal of Modern European History. München: C.H.Beck. ISSN (online) 1611-8944. Volume 13. N. ${ }^{\circ} 1$ (2015) p. 98-114. 
GRIFFIN, Roger - "Fixing Solutions: Fascist Temporalities as Remedies for Liquid Modernity". Journal of Modern European History. München: C.H.Beck. ISSN (online) 1611-8944. Volume 13, N. ${ }^{\circ} 1$ (2015) p. 5-23.

GUILLAUME, Marc - A politica do património. Trad. Joana Caspurro. Porto: Campo das Letras, 2003. 152 p. ISBN 972-610-704-0.

HARLANDER, Tilman - "Urbanism and Housing Policy in Nazi Germany: A Commentary". In BODENSCHATZ, Harald; SASSI, Piero; WELSH GUERRA, Max - Urbanism and Dictatorship: A European Perspective. Basel: Birkhäuser, 2015. ISBN 978-3-03821-690-2. p. $148-165$.

HERCULANO, Alexandre - "A Architectura Gothica". O Panorama: Jornal Litterário e Instructivo da Sociedade Propagadora dos Conhecimentos Úteis. V.o 1. N.o 1 (1837) p. 2-4.

HERCULANO, Alexandre - "A Eschóla Polytechnica e o Monumento: Conhecimentos Uteis". Revista Universal Lisbonense: Jornal dos interesses physicos, moraes e litterarios por uma sociedade estudiosa. Vol. 2. N. 38 (1843) p. 469-473.

HERCULANO, Alexandre - Opúsculos: Questôes Públicas: Tomo II. Lisboa: Viúva Bertrand, 1873.

LEAL, José Mendes. Monumentos Nacionaes. Lisboa: Typographia Franco - Portugueza, 1868. $198 \mathrm{p}$.

MatTosO, J.; DAVEAU, S.; BelO, D. - Portugal: O Sabor da Terra. [Lisboa]: Círculo de Leitores / EXPO'98, 1997. 220 p. ISBN 972-42-1554-7.

OLIVEIRA SALAZAR, António - "Defesa económica - Defesa moral - Defesa política" (25 de Junho de 1942). In Coimbra Editora (Ed.) - Discursos e notas politicas, Vol. III: 1938-1943. Coimbra: Coimbra Editora, 1944. p. 319-352.

OLIVEIRA SALAZAR, António - "Os princípios e a obra da Revoluçáo no momento interno e no momento internacional" (27 de Abril de 1943). In Coimbra Editora (Ed.) - Discursos e notas políticas, Vol. III: 1938-1943. Coimbra: Coimbra Editora, 1944. p. 381-415.

OLIVEIRA SALAZAR, António - "No encerramento da Exposição de Obras Públicas" (7 de Novembro de 1948). In Coimbra Editora (Ed.) - Discursos e notas politicas, Vol. IV: 1943-1950. Coimbra: Coimbra Editora, 1951. p. 339-345.

OPPEN, Christian von - "Urbanism: The Driving Force and Stage of the Portuguese Dictatorship". In BODENSCHATZ, Harald; SASSI, Piero; WELSH GUERRA, Max - Urbanism and Dictatorship: A European Perspective. Basel: Birkhäuser, 2015. ISBN 978-3-03821-690-2. p. 102-116.

ORTIGÃO, Ramalho - O Culto da Arte em Portugal. Lisboa: A.M. Pereira, 1896. 176 p.

PABLO, Ainhoa Díez de - "Preservation of Franco’s Social Housing Estates in Madrid". In BODENSCHATZ, Harald; SASSI, Piero; WELSH GUERRA, Max - Urbanism and Dictatorship: A European Perspective. Basel: Birkhäuser, 2015. ISBN 978-3-03821-690-2. p. 135-147.

PEGORIN, Elisa - "Architettura e regime tra Italia e Portogallo. Relazione nelle opere pubbliche dello Estado Novo". Estudos Italianos em Portugal. Lisboa: Instituto de Estudos Italianos. ISSN 0870-8584. Nova Série, N. ${ }^{\circ} 12$ (2017) p. 83-95.

PEREIRA, Gabriel - "Monumentos Nacionaes". A Architectura Portugueza: Revista Mensal da Arte Architectural Antiga e Moderna. No 3 (1908) p. 11-12.

PIRES, Ema Cláudia - O Baile do Turismo. Turismo e Propaganda no Estado Novo. Casal de Cambra: Caleidoscópio, 2003. 125 p. ISBN 9728801025. 
ROSA, João Pereira da (Dir.) - "As Pedras Sagradas de Portugal”. O Século Ilustrado. (1939, 27 de Maio) p. 16-17.

ROSA, João Pereira da (Dir.) - “[Símbolos da Pátria!]”. O Século Ilustrado. (1940, 15 de Junho) p. 1.

ROSAS, Fernando - Salazar e o Poder: A Arte de Saber Durar. Lisboa: Ediçóes Tinta-da-China, 2012. 367 p. ISBN 9789896711405.

ROSAS, Lúcia - Monumentos Pátrios: A arquitectura religiosa medieval - património e restauro (1835-1928). Tese de Doutoramento. Porto: Faculdade de Letras da Universidade do Porto, 1995.

SAMBRICIO, Carlos - "On Urbanism in the Early Years of Francoism". In BODENSCHATZ, Harald; SASSI, Piero; WELSH GUERRA, Max - Urbanism and Dictatorship: A European Perspective. Basel: Birkhäuser, 2015. ISBN 978-3-03821-690-2. p. 117-134.

SANTOS, L. R.; QUEIROZ, C. - Paisagem e Monumentos de Portugal. Lisboa: Edição da Secção de Propaganda e Recepção da Comissão Nacional dos Centenários, 1940.

SCHEFFLER, Tanja - "The Technical Fairground in Leipzig in the Period of National Socialism". In BODENSCHATZ, Harald; SASSI, Piero; WELSH GUERRA, Max - Urbanism and Dictatorship: A European Perspective. Basel: Birkhäuser, 2015. ISBN 978-3-03821-690-2. p. 166-182.

SEIXAS LOPES, Diogo - Melancolia e Arquitectura em Aldo Rossi. Trad. Jorge Colaço. Lisboa: Orfeu Negro, 2016. 312 p. ISBN 978-989-8327-83-3.

SEVILlA-BUITRAGO, Álvaro - "Urbanism and Dictatorship: Perspectives of the Field of Urban Studies". In BODENSCHATZ, Harald; SASSI, Piero; WELSH GUERRA, Max - Urbanism and Dictatorship: A European Perspective. Basel: Birkhäuser, 2015. ISBN 978-3-03821-690-2. p. 27-35.

SPIEGEL, Daniela - "Urbanism in Fascist Italy: All Well and Good?". In BODENSCHATZ, Harald; SASSI, Piero; WELSH GUERRA, Max - Urbanism and Dictatorship: A European Perspective. Basel: Birkhäuser, 2015. ISBN 978-3-03821-690-2. p. 43-58.

SPN - Portugal 1934. Lisboa: Edições SPN, [1934]. 39 p.

SPN - Images Portugaises. Lisboa: Ediçôes SPN, [1939].

SPN - "Païsagem e Monumentos de Portugal". Panorama: Revista Portuguesa de Arte e Turismo. N. ${ }^{\circ} 1$ (1941) p. 20-21.

SPN - Obras Públicas: Cadernos do Ressurgimento Nacional. Lisboa: Ediçóes SPN, [1943].

TEOTÓNIO PEREIRA, Nuno; FERNANDES, José Manuel - "A Arquitectura do Fascismo em Portugal”. In PINTO, António Costa [et al.] - O Fascismo em Portugal: Actas do Colóquio. Lisboa: Regra do Jogo, 1982. p. 533-551.

WELSH GUERRA, Max - "Urbanism, Dictatorship and Historiography: A Contextualization". In BODENSCHATZ, Harald; SASSI, Piero; WELSH GUERRA, Max - Urbanism and Dictatorship: A European Perspective. Basel: Birkhäuser, 2015. ISBN 978-3-03821-690-2. p. 217-228.

WINCKELMANN, Johann Joachim - Geschichte der Kunst des Alterthums. Dresden: Walther, 1764. 